\title{
Air Quality and Health Benefits of Methane Policies in the United States Oil \& Gas Sector
}

\section{Jonathan Buonocore ( $\nabla$ jbuonocore@mail.harvard.edu )}

Center for Climate, Health, and the Global Environment, Harvard T.H. Chan School of Public Health https://orcid.org/0000-0001-7270-892X

\section{Srinivas Reka}

University of North Carolina

\section{Dongmei Yang}

University of North Carolina

Charles Chang

University of North Carolina

\section{Ananya Roy}

Environmental Defense Fund

\section{Tammy Thompson}

Environmental Defense Fund

\section{David Lyon}

Environmental Defense Fund

\section{Renee McVay}

Environmental Defense Fund

\section{Drew Michanowicz}

Physicans, Scientists, and Engineers for Healthy Energy

\section{Saravanan Arunachalam}

The University of North Carolina at Chapel Hill, Institute for the Environment, Chapel Hill, United States https://orcid.org/0000-0002-6836-6944

\section{Analysis}

Keywords: Air Pollution, Methane Reduction Policy, Health Co-benefits, Oil \& Gas Production

Posted Date: March 4th, 2021

DOl: https://doi.org/10.21203/rs.3.rs-199686/v1

License: (9) This work is licensed under a Creative Commons Attribution 4.0 International License. Read Full License 

Title: Air Quality and Health Benefits of Methane Policies in the United States Oil \& Gas Sector

Authors: Jonathan J Buonocore ${ }^{1}$, Srinivas Reka ${ }^{2}$, Dongmei Yang ${ }^{2}$, Charles Chang ${ }^{2}$, Ananya Roy $^{3}$, Tammy Thompson ${ }^{3}$, David Lyon ${ }^{3}$, Renee McVay ${ }^{3}$, Drew Michanowicz ${ }^{4}$, Saravanan

Arunachalam ${ }^{2}$

${ }^{1}$ Center for Climate, Health, and the Global Environment, Harvard T.H. Chan School of Public Health, Boston, MA, USA

${ }^{2}$ Institute for the Environment, University of North Carolina, Chapel Hill, NC, USA

${ }^{3}$ Environmental Defense Fund, Washington, DC, USA

${ }^{4}$ Physicians, Scientists, and Engineers for Healthy Energy, Oakland, CA, USA

Submitted as a Policy Analysis to Nature Climate Change

3000 words as main body (intro, brief methods, results, discussion conclusion), methods in supplemental (no word limit), 6 visual objects

Abstract: 149

Intro: 617

Results: 1398

Discussion: 983

Total: 2998

$\leq 50$ methods in the references for the main section

Title $\leq 90$ characters (including spaces)

Abstract $\leq 150$ words

\section{Abstract:}

In 2016, air pollution from oil \& gas (O\&G) production in the U.S. resulted in 7,500 (95\% Cl: $4,500-12,000$ ) excess deaths among many other health impacts, valued at $\$ 77$ billion (\$2016 USD) (95\% Cl: $\$ 27$ billion - $\$ 170$ billion). An ambitious methane reduction policy in 2028 would result in 1,400 (820 - 2,300) deaths compared to 2028 business as usual, while other policies would have modest effects. Regions without O\&G activity experienced impact from the sector and benefits from emissions reductions. On a per ton basis, the health co-benefits per methane reduction from each policy were $\sim 5 x$ lower than health co-impacts from the whole production sector, since policies only apply to specific O\&G production processes. We show that there are still substantial health co-benefits to policies that reduce methane emissions, however the health co-benefits can be enhanced if emissions reduction policies cover more components of O\&G production. 


\section{Introduction:}

Emissions pathways that keep global warming to $1.5^{\circ} \mathrm{C}$ with little to no exceedance within the next 20 to 40 years generally involve steep near-term methane $\left(\mathrm{CH}_{4}\right)$ reductions ${ }^{1}$. Since methane is a potent short-lived climate pollutant (SLCP - greenhouse gases (GHGs) much more potent but shorter-lived than $\mathrm{CO}_{2}$ ) - with global warming potential 84-85 times higher than $\mathrm{CO}_{2}$ over a 20 -year period, methane emissions control is critical to meeting the near-term goals of the Paris Agreement ${ }^{1,2}$.

The U.S. Environmental Protection Agency (U.S. EPA) estimates that natural gas and petroleum production and transportation systems are the second largest emitters of methane emitting 7.05 million metric tons (MMT) in $2018^{3}$. Research on 2015 emissions indicates this may be underestimated by $\sim 60 \%{ }^{4}$. Mitigating emissions from O\&G may also have immediate benefits to air quality and public health. Many non-methane volatile organic compounds (NMVOCs) are emitted alongside methane ${ }^{5}$, contributing to the O\&G sector being the largest anthropogenic source of VOCs. Also, many O\&G production processes involve fuel combustion resulting in emissions of nitrogen oxides $\left(\mathrm{NO}_{x}\right)$, sulfur dioxide $\left(\mathrm{SO}_{2}\right)$, ammonia $\left(\mathrm{NH}_{3}\right)$, and fine particulate matter $\left(\mathrm{PM}_{2.5}\right)^{5}$, all of which contribute to air pollution and health impacts ${ }^{6,7} . \mathrm{PM}_{2.5}$, ozone, and $\mathrm{NO}_{2}$ are of concern from a regional air pollution and health standpoint, since they are associated with increased risk of premature death, respiratory and cardiovascular hospitalizations, heart attack, asthma, birth outcomes, among other health impacts ${ }^{8-11}$. While there has been research on health co-benefits of GHG emission reduction strategies in transportation, electricity, buildings, and other energy consuming sectors ${ }^{12-18}$, far less research has been done on the health benefits of policies that reduce methane emissions, especially from O\&G production. Previous O\&G impact assessments have not used atmospheric models with detailed ozone or chemistry on how VOC emissions affect $\mathrm{PM}_{2.5}$ formation, updated epidemiology on increased mortality risk and exposure to ozone or $\mathrm{NO}_{2}$, or assessed impacts on children, notably asthma ${ }^{19,20}$.

Here, we assess the current air quality and health impacts from the sector, and then estimate the potential co-benefits of a set of methane emissions reduction policies on the O\&G sector in the U.S., compared to a "business as usual" (BAU) case in 2028. Our BAU case is developed from a base case from the U.S. EPA, modified to incorporate current Federal and state regulations. Three additional policy cases are an "Ambitious" case with strong federal and state regulations (including strong federal standards for both new and existing wells, details in Table S1), a "Strong State" case which incorporates strong regulations passed in a set of O\&G producing states with current federal regulations, and a "Rollback" case with the effects of the 2018 reconsideration and 2019 rollback of the New Source Performance Standards (NSPS) for O\&G wells but maintaining existing state regulations. The Ambitious, Strong State with Federal BAU, EPA Base Case, and Rollback scenarios were each compared to the BAU.

We evaluate the air quality and health consequences of O\&G emissions in 2016 and these policy scenarios for 2028, using a novel framework that accepts geospatial emissions data under different policies, and simulates the consequent air pollution using the Community 
Multiscale Air Quality Model version 5.2.1 (CMAQ) ${ }^{21}$, an air pollution chemistry and transport model with advanced representation of carbon chemistry. This air pollution model output is then linked to a geospatial air pollution health impact assessment platform BenMAPR (similar to the U.S. Environmental Protection Agency Environmental Benefits Mapping and Analysis Program $(\text { BenMAP })^{22,23}$ ), which contains geospatial data on population, background disease rates, and a series of concentration response functions (CRFs) providing the relationship between exposure to the air pollutants $\mathrm{PM}_{2.5}$, ozone, and $\mathrm{NO}_{2}$. This platform is then used to assess and compare the magnitude and distribution of the health impacts of air pollution under different emissions scenarios.

\section{Results:}

Oil \& gas emissions, air pollution, and health in 2016

The major emissions of $\mathrm{CH}_{4}$ and NMVOCs from the O\&G sector accounts for about 21 and 2.9 million tons followed by $\mathrm{NO}_{x}, \mathrm{SO}_{2}, \mathrm{PM}_{2.5}$ and $\mathrm{NH}_{3}$ in 2016 (Table 1). These emissions contributed between $-0.001-1.682 \mu \mathrm{g} / \mathrm{m} 3$ of $\mathrm{PM}_{2.5},-0.42$ to $2.7 \mathrm{ppb}$ of ozone, and between 0.014 and $17.2 \mathrm{ppb}$ of $\mathrm{NO}_{2}$ across our modeling domain. This additional pollution was enough to result in 29 instances of $12 \times 12 \mathrm{~km}$ grid cells exceeding the daily PM2.5 National Ambient Air Quality Standard (NAAQS), 1 exceedance of the annual PM2.5 NAAQS and 634 exceedances of the annual ozone NAAQS, generally downwind of oil \& gas producing regions (Table 1, S2), made up of a mix of largely $\mathrm{NO}_{3}, \mathrm{NH}_{3}$, and organic matter (Figure S1-2, Table S3).

In 2016, the total health impacts of air pollution from the O\&G sector included 7,500 $(95 \% \mathrm{Cl}$ : 4,500 - 12,000) lives lost, 2,200 (95\% Cl: 830 - 3,200) new childhood asthma cases, and 410,000 (95\% Cl: 9,200 - 810,000) asthma exacerbations with total value of $\$ 77$ billion ( $\$ 27$ billion - $\$ 170$ billion). Of the deaths in 2016 due to O\&G pollution, 2,100 (28\%) were due to $\mathrm{PM}_{2.5}, 2,600$ (35\%) were due to ozone, and 2,800 (37\%) were due to $\mathrm{NO}_{2}$ (Tables 2, S4).

The spatial distribution of the impacts follows a spatial pattern that reflects the underlying changes in air quality intersected with population distribution (Figures 2, S3, and S4). Reductions in mortality cases per million people are largely centered around O\&G producing areas - TX, LA, OK, western PA, WV, and ND, and a few counties in CO, WY, and NM. Childhood asthma follows a spatial pattern that is similar but more tightly constrained, since only $\mathrm{PM}_{2.5}$ and $\mathrm{NO}_{2}$ exposure contribute. Many heavily impacted cities are near $\mathrm{O} \& \mathrm{G}$ activity, including Denver CO, cities in TX including Dallas, Houston, Fort Worth, and San Antonio, and Pittsburgh PA. However, some cities far downwind also experience substantial impact Chicago IL, Boston, MA, New York, NY, Philadelphia, PA, Washington DC, and Baltimore, MD, all experience some health impact from O\&G air pollution. This is reflected in the state ranking of health impacts (Figure 3 ) - states with heavy O\&G activity and emissions, like TX, OK, and PA, generally have the highest total impact, but some heavily populated states that are downwind of O\&G states, but do not have O\&G activity themselves, like IL, NY, and GA have health impact from O\&G higher in proportion than their emissions. Some states with high O\&G related emissions but low population, like ND and NM, end up being much less heavily impacted due to their low populations. 
Emissions, Air Pollution, and Health Benefits and Impacts of Scenarios for 2028

The benefits or impacts of each policy are consistent with the direction and degree of ambition of each policy (Tables S5 - S14, Figures S5 - S9). Compared to BAU, the benefits of our Ambitious case are highest, followed by our Strong State scenario (Figure 4, Table 2). The Rollback case results in some health burden, consistent with the increases in emissions under this policy, and the resulting health burden of EPA Base scenario are even higher. reflecting the benefits of emissions reductions from state policies present under BAU, but absent under the EPA base case. Health benefits or impacts occur in areas that experience emissions reductions or increases, and areas downwind. The monetized value of the health benefits or impacts of each policy are similar to the monetized value of the climate benefits or impacts, despite the total economic value of health impacts of $O \& G$ production drastically exceeding the economic value of the climate impacts from O\&G production.

\section{Emissions Reductions}

Across the different policy scenarios, emissions reductions of methane and other air pollutants roughly followed the degree of ambition of the policies. Reductions in NMVOCs and $\mathrm{NO}_{x}$ also roughly track the ambition of each policy scenario (Table 1). The highest reductions were in the Ambitious Scenario, with 9.3 million tons of $\mathrm{CH}_{4}$ reduced, and lower in the Strong State scenario (5.8 million tons $\mathrm{CH}_{4}$ ), an increase in emissions in the Federal Rollback scenario, and higher increases in the EPA base case (Table 1).

\section{Air Quality Improvements}

Air quality changes also generally followed the degree of ambition in each policy scenario (Fig 1, S5-9). However, there is a wide range of changes in air pollution concentrations across the geographical domain in each of the 4 scenarios. In our Ambitious scenario, ozone improvements are the most widely spread, with nearly all states experiencing ozone improvement, and the greatest ozone improvements occurring in TX, LA, AR, NM, and OK (0.1$1.3 \mathrm{ppb}$ ). $\mathrm{PM}_{2.5}$ is somewhat more tightly constrained, with greatest improvements occurring around O\&G producing regions in TX, OK, NM, Western PA, WV, and northern MI (0.01$\left.0.75 \mathrm{~g} / \mathrm{m}^{3}\right) . \mathrm{NO}_{2}$ improvements are even more tightly geographically constrained and roughly follow the same spatial pattern as $\mathrm{PM}_{2.5}$ reductions, with areas in TX, LA, NM, AL, AR, the border between OK and KS, northern MI, WV, and western PA (0.01-6.8 ppb). The $\mathrm{PM}_{2.5}$ reduced is largely from reduced nitrate (29.5\%) and organic carbon (33.4\%) (Figure S2 and Table S3), related to changes in NOx and VOC emissions respectively. Under the rollback scenario, ozone concentrations increase in areas of TX, OK, NM, CO, UT, PA, and WV (0.01$0.1 \mathrm{ppb}), \mathrm{PM}_{2.5}$ concentrations decrease in $\mathrm{PA}, \mathrm{OH}$, and $\mathrm{MN}\left(0.001-0.01 \mathrm{~g} / \mathrm{m}^{3}\right)$, and there is very little change in $\mathrm{NO}_{2}$ concentrations.

NAAQS analyses of ozone and PM2.5: 
Compared to 2016, the 2028 base case (BAU) shows substantial reductions in days where ozone and $\mathrm{PM}_{2.5}$ exceeded U.S. EPA regulatory thresholds (Table 1). Compared to $2028 \mathrm{BAU}$, the Ambitious case shows the most benefits for both ozone (20\%; especially during the summer season; Table S4) and daily $\mathrm{PM}_{2.5} ; 38 \%$; for the year 2028; Table 1). The Strong State with Federal BAU and EPA Base Case scenarios both show relatively modest benefits and very modest disbenefits, while the rollback scenario shows no impact for these metrics (Table 1).

\section{Health Benefits}

The total health impacts of the O\&G sector under a BAU scenario in 2028 are higher than in $2016,8,700(5,200$ - 14,000) lives lost, 2,300 (870 - 3,500) new childhood asthma cases, and $410,000(8,900-810,000)$ asthma exacerbations (Table 2$)$. The total value of health impacts was $\$ 90$ billion ( $\$ 2016$ USD) ( $\$ 32$ billion - $\$ 210$ billion). Proportions across pollutants were similar to 2016, with 2,700 deaths due to $\mathrm{PM}_{2.5}$ reductions (31\%), 3,300 (38\%) due to ozone reductions, and 2,700 (31\%) due to $\mathrm{NO}_{2}$ reductions. When population growth and aging is incorporated, the 2028 health burden increases reflected an aging population - cases of hospitalizations and other outcomes only affecting those $\geq 65$ years went up by near $50 \%$, attributable deaths went up by $7 \%$, and asthma cases went up by less than $1 \%$ (Tables S5S14).

The health benefits of each policy scenario also follow the degree of ambition of each policy. The ambitious scenario resulted in 1,400 (95\% Cl: 820 - 2,300) lives saved, 390 (95\% Cl: 150 $570)$ asthma cases avoided, and 77,000 (95\% Cl: 1,800 - 150,000) asthma exacerbations avoided (Table 2). In contrast, the rollback scenario resulted in between 16 lives lost and 3 lives saved and 2.7 to 16 new asthma cases produced. The proportions by pollutant varied between policy scenarios. Under the ambitious case, $43 \%$ of deaths avoided were from ozone reduction, $22 \%$ from $\mathrm{PM}_{2.5}$, and $37 \%$ from $\mathrm{NO}_{2}$. Under the rollback scenario, there was an increase in deaths due to ozone with some reduction in deaths due to $\mathrm{PM}_{2.5}$, and little change from $\mathrm{NO}_{2}$. With 2030 population projections, the changes were similar to those under the $2028 \mathrm{BAU}$ (Tables S5-14).

Health benefits per methane reduction

In 2028, the health co-impacts of air pollution from O\&G were worth approximately $\$ 6,400$ per ton of methane - approximately $5 x$ the social cost of the methane emissions (Figure 4). Compared to the total impacts of O\&G production, the policies evaluated here benefit health more than climate. For each policy case, the value of the health impacts or benefits is similar to that of the climate benefits (Figure 4). Compared to BAU, the Ambitious case reduces methane emissions by slightly over half and health impacts of O\&G by around 1/6th (Figure 4, Tables 1 and 2). The Strong State scenario cuts emissions by nearly a third, but health impacts by around 2\% (Figure 4, Tables 1 and 2).

\section{Discussion:}


In 2016, there was a substantial health impact of air pollution from oil and gas production that is projected to increase slightly through 2028 , independent of population growth and aging. The impacts of air pollution from $O \& G$ are fairly concentrated in regions with $O \& G$ production, with some regional spread to areas outside major $\mathrm{O} \& \mathrm{G}$ producing regions. $\mathrm{NO}_{2}$ is the largest contributor to health impacts, followed by ozone and then $\mathrm{PM}_{2.5}$. $\mathrm{NO}_{2}$ impacts are the most tightly constrained, and ozone is the most dispersed, and regional spread is substantial. The 5 states with the highest impacts due to O\&G pollution - TX, PA, OH, OK, and LA - all have high levels of O\&G activity. However, IL and NY have the 6th and 8th highest impact, despite having little $O \& G$ activity in-state.

The health benefits of the policies follow the degree of ambition of the policy. Benefits are moderately concentrated in areas where emissions reductions occur, with some impacts occurring in areas downwind, and similar geographical patterns of benefits by exposed pollutant type. The rollback scenario has some complexities apparent in trends by pollutant, where there is increasing $\mathrm{PM}_{2.5}$ concentrations in some areas, and decreasing ozone in others, likely reflecting regional differences in chemical regimes and complex interactions between pollutants. Policies that reduce methane can have substantial health benefits but compared to the total impact of the sector, benefit climate proportionately more than health. This indicates that emissions from $O \& G$ production processes that are not affected by these methane reduction policies have a strong role to play in health impacts, and that the health benefits of O\&G policies can be enhanced by also reducing other emissions, like $\mathrm{NO}_{\mathrm{x}}$.

Our results here are subject to a number of uncertainties throughout the modeling chain. The emissions inventories used here most likely underestimate actual methane emissions from the O\&G sector ${ }^{4}$ and are likely to underestimate NMVOC emissions as well. Additionally, the number of compressor stations in the emissions inventory may also be undercounted. In Pennsylvania (PA), for example, the EPA inventory of point sources in 2017 contains 72 compressor stations in $\mathrm{PA}^{5}$. A recent study in PA found that 361 compressor stations were operational in $2013^{24}$. Additionally, the PA Department of Environmental Protection (PA DEP) has 353 permitted compressor stations in 2013 and 547 permitted in $2016^{25}$. These missing emissions, along with uncertainties in the CMAQ model and interactions with these missing emissions introduce additional uncertainty. The spatial resolution of the atmospheric modeling, while rather robust for most regional-scale applications and when compared to global-scale models, limits our ability to capture fine scale effects, which are likely to be important near O\&G operations. Even though the CRFs have independent health effect estimates, there could still be residual double-counting between pollutants. Additionally, the CRFs and background health data used here do not capture differences by race/ethnicity, income, or education levels; morbidity outcomes are generally at state level rather than county level. This limits our ability to capture possible interactions leading to increased impact in communities near O\&G activity. Since our model exclusively captures health impacts from three of the criteria pollutants that have national health-based standards - ozone, $\mathrm{PM}_{2.5}$, and $\mathrm{NO}_{2}-$ we omit health benefits from reductions to other hazardous pollutants that can exist at high concentrations near O\&G production, like benzene, toluene, ethylbenzene, xylene, formaldehyde, and acetaldehyde, among others ${ }^{26,27}$. Additionally, this study focuses on air quality and health impacts from $O \& G$ 
production - the "upstream" portion of the supply chain. This assessment is a component of a full assessment of the health costs of gas across the life cycle. Impacts associated with midstream and downstream leakage and combustion, along with hazardous air pollutants, water pollutants, and safety are not included here.

Despite these limitations, we demonstrate substantial public health impact from the O\&G sector, and substantial benefits of policies that reduce $\mathrm{CH}_{4}$ emissions and co-pollutants. We demonstrate this using a robust method to evaluate health benefits of policies that makes substantial advancements from previous models for health benefits of climate policies ${ }^{12-15,17}$. These advancements include new health-relevant air pollutants, detailed chemistry relevant to pollutant formation ${ }^{6,28}$, updated epidemiology showing the relationship between long-term exposure to ozone ${ }^{9}$ and increased mortality risk, and include impacts due to long-term $\mathrm{NO}_{2}$ exposure ${ }^{10}$. Most prior assessments of health benefits of GHG reduction policies focus on reducing combustion-related $\mathrm{CO}_{2}$ emissions, and the health benefits of co-emitted $\mathrm{PM}_{2.5}, \mathrm{PM}_{2.5}$ precursors, and occasionally ozone ${ }^{17}$. Our $\mathrm{PM}_{2.5}$ and ozone exposures are similar to previous work modeling the health impacts of O\&G production ${ }^{19}$, and our finding of elevated ozone concentrations, and widespread ozone formation of O\&G in the central U.S. is similar to satellite observations ${ }^{29}$ and modeling studies ${ }^{19,30}$. Our estimates of the health impacts of $P_{2.5}$ from $O \& G$ are fairly similar to previous findings ${ }^{19}$. However, our results for health impacts of ozone are much higher, reflecting our use of a CRF for long-term exposure to ozone ${ }^{9,19}$. That, alongside our inclusion of $\mathrm{NO}_{2}$, results in substantially higher total health impacts of O\&G production. Our work demonstrates that there are health benefits of climate policies outside those targeted toward reducing fuel combustion. It also shows that assessments focusing on $\mathrm{PM}_{2.5}$, that do not include long-term exposure to ozone or $\mathrm{NO}_{2}$, may be substantially underestimating total health benefits of policies.

O\&G production has substantial health impacts alongside the climate impacts from methane emissions, and reducing methane emissions can have substantial health benefits through reducing exposure to ozone, $\mathrm{PM}_{2.5}$, and $\mathrm{NO}_{2}$. These health impacts, and the benefits of policies, can extend well outside O\&G producing regions, and make substantial contributions to air pollution and health impacts in populated areas far from O\&G producing regions. However, policies which also reduce emissions from other components of O\&G production alongside methane will likely lead to even higher health benefits. If used in policy decisions, information on health benefits and their distribution can ensure that policies benefit public health, and substantially reduce the pollution burden for communities near O\&G production.

\section{Acknowledgements:}

This work was financially supported by grants from the High Tide Foundation and the Environmental Defense Fund. We would like to thank Alique Berberian and Frederica Perera for assistance compiling concentration response functions and background health data for health outcomes in children. We acknowledge Alison Eyth and Jeffrey Vukovich of the U.S. EPA for providing emissions inventories from the NEI collaboratory, and to all air quality scientists across multiple state, local, tribal, and regional agencies, and EPA and Federal Land Management agencies who were involved in the development of the national inventories. We 
would also like to thank attendees of our presentations at the American Geophysical Union conference in 2019 and the American Meteorological Society in 2021 for their feedback on initial results from this work.

\section{References:}

1. IPCC, 2018: Summary for Policymakers. in Global Warming of $1.5^{\circ} \mathrm{C}$. An IPCC Special Report on the impacts of global warming of $1.5^{\circ} \mathrm{C}$ above pre-industrial levels and related global greenhouse gas emission pathways, in the context of strengthening the global response to the threat of climate change, sustainable development, and efforts to eradicate poverty (eds. Masson-Delmotte, V. et al.).

2. Collins, W. J. et al. Increased importance of methane reduction for a 1.5 degree target. Environ. Res. Lett. 13, 054003 (2018).

3. U.S. Environmental Protection Agency. Inventory of U.S. Greenhouse Gas Emissions and Sinks: 1990-2018. https://www.epa.gov/sites/production/files/2020-04/documents/us-ghginventory-2020-main-text.pdf (2020).

4. Alvarez, R. A. et al. Assessment of methane emissions from the U.S. oil and gas supply chain. Science eaar7204 (2018) doi:10.1126/science.aar7204.

5. U.S. Environmental Protection Agency. National Emissions Inventory. National Emissions Inventory https://www.epa.gov/air-emissions-inventories/national-emissions-inventory-nei.

6. Appel, K. W. et al. Description and evaluation of the Community Multiscale Air Quality (CMAQ) modeling system version 5.1. Geosci. Model Dev. 10, 1703-1732 (2017).

7. Gilmore, E. A. et al. An inter-comparison of the social costs of air quality from reducedcomplexity models. Environ. Res. Lett. 14, 074016 (2019).

8. Vodonos, A., Awad, Y. A. \& Schwartz, J. The concentration-response between long-term PM2.5 exposure and mortality; A meta-regression approach. Environmental Research 166, 677-689 (2018). 
9. Turner, M. C. et al. Long-Term Ozone Exposure and Mortality in a Large Prospective Study. Am J Respir Crit Care Med 193, 1134-1142 (2016).

10. Faustini, A., Rapp, R. \& Forastiere, F. Nitrogen dioxide and mortality: review and metaanalysis of long-term studies. European Respiratory Journal 44, 744-753 (2014).

11. European Environment Agency. Air quality in Europe: 2020 report. (Publications Office, 2020).

12. Buonocore, J. J. et al. Climate and health benefits of increasing renewable energy deployment in the United States. Environ. Res. Lett. 14, 114010 (2019).

13. Driscoll, C. T. et al. US power plant carbon standards and clean air and health co-benefits. Nature Clim Change 5, 535-540 (2015).

14. Buonocore, J. J., Levy, J. I., Guinto, R. R. \& Bernstein, A. S. Climate, air quality, and health benefits of a carbon fee-and-rebate bill in Massachusetts, USA. Environ. Res. Lett. 13, 114014 (2018).

15. P., M. et al. Energy savings, emission reductions, and health co-benefits of the green building movement. J Expo Sci Environ Epidemiol 28, 307-318 (2018).

16. Thompson, T. M., Rausch, S., Saari, R. K. \& Selin, N. E. A systems approach to evaluating the air quality co-benefits of US carbon policies. Nature Clim Change 4, 917-923 (2014).

17. Chang, K. M. et al. Ancillary health effects of climate mitigation scenarios as drivers of policy uptake: a review of air quality, transportation and diet co-benefits modeling studies. Environ. Res. Lett. 12, 113001 (2017).

18. Creutzig, F. \& He, D. Climate change mitigation and co-benefits of feasible transport demand policies in Beijing. Transportation Research Part D: Transport and Environment 14, 120-131 (2009).

19. Fann, N. et al. Assessing Human Health $\mathrm{PM}_{2.5}$ and Ozone Impacts from U.S. Oil and Natural Gas Sector Emissions in 2025. Environ. Sci. Technol. 52, 8095-8103 (2018). 
20. Litovitz, A., Curtright, A., Abramzon, S., Burger, N. \& Samaras, C. Estimation of regional airquality damages from Marcellus Shale natural gas extraction in Pennsylvania. Environ. Res. Lett. 8, 014017 (2013).

21. Byun, D. \& Schere, K. L. Review of the Governing Equations, Computational Algorithms, and Other Components of the Models-3 Community Multiscale Air Quality (CMAQ) Modeling System. Appl. Mech. Rev. 59, 51 (2006).

22. U.S. Environmental Protection Agency. Environmental Benefits Mapping and Analysis Program - Community Edition (BenMAP-CE).

23. Sacks, J. D. et al. The Environmental Benefits Mapping and Analysis Program - Community Edition (BenMAP-CE): A tool to estimate the health and economic benefits of reducing air pollution. Environ Model Softw 104, 118-129 (2018).

24. Koehler, K. et al. Exposure Assessment Using Secondary Data Sources in Unconventional Natural Gas Development and Health Studies. Environ. Sci. Technol. 52, 6061-6069 (2018).

25. Pennsylvania Department of Environmental Protection. Air Quality Reports. https://www.dep.pa.gov/DataandTools/Reports/Pages/Air-Quality-Reports.aspx.

26. Adgate, J. L., Goldstein, B. D. \& McKenzie, L. M. Potential Public Health Hazards, Exposures and Health Effects from Unconventional Natural Gas Development. Environ. Sci. Technol. 48, 8307-8320 (2014).

27. Elliott, E. G. et al. A community-based evaluation of proximity to unconventional oil and gas wells, drinking water contaminants, and health symptoms in Ohio. Environmental Research 167, 550-557 (2018).

28. Houyoux, M. R., Vukovich, J. M., Coats, C. J., Wheeler, N. J. M. \& Kasibhatla, P. S. Emission inventory development and processing for the Seasonal Model for Regional Air Quality (SMRAQ) project. J. Geophys. Res. 105, 9079-9090 (2000). 
29. Pozzer, A., Schultz, M. G. \& Helmig, D. Impact of U.S. Oil and Natural Gas Emission Increases on Surface Ozone Is Most Pronounced in the Central United States. Environ. Sci. Technol. acs.est.9b06983 (2020) doi:10.1021/acs.est.9b06983.

30. Thompson, T. M., Shepherd, D., Stacy, A., Barna, M. G. \& Schichtel, B. A. Modeling to Evaluate Contribution of Oil and Gas Emissions to Air Pollution. Journal of the Air \& Waste Management Association 67, 445-461 (2017).

Tables:

Table 1: Oil and gas sector emissions and source contribution to air quality. Results for each scenario are compared to that year's BAU.

\begin{tabular}{|c|c|c|c|c|c|c|c|}
\hline & & 2016 & 2028 (polic & y case - BAU & & & \\
\hline & & $\begin{array}{l}\text { Full Health } \\
\text { Burden of } \\
\text { Sector } \\
\text { Emissions }\end{array}$ & \begin{tabular}{|l} 
Strong \\
Federal \\
and State
\end{tabular} & \begin{tabular}{|l} 
Federal \\
BAU and \\
Strong \\
State
\end{tabular} & \begin{tabular}{|l} 
EPA \\
Base \\
Case
\end{tabular} & Rollback & \begin{tabular}{|l|} 
Full \\
Burden of \\
Sector \\
Emission \\
$\mathbf{s}$
\end{tabular} \\
\hline \multirow{6}{*}{$\begin{array}{l}\text { Emissions } \\
\text { contributio } \\
\mathrm{n} \\
\text { (tons/year) }\end{array}$} & $\mathrm{CH}_{4}$ & $\begin{array}{c}21,343,54 \\
8\end{array}$ & $\begin{array}{c}- \\
9,319,551\end{array}$ & $-5,752,507$ & $\begin{array}{c}4,138,73 \\
6\end{array}$ & $\begin{array}{c}728,17 \\
4\end{array}$ & $\begin{array}{c}13,969,7 \\
39\end{array}$ \\
\hline & NMVOCs & $2,994,766$ & $\begin{array}{c}- \\
1,020,042\end{array}$ & $-125,350$ & 45,689 & $\begin{array}{c}163,82 \\
5\end{array}$ & $\begin{array}{c}3,520,87 \\
2\end{array}$ \\
\hline & $\mathrm{NO}_{x}$ & $1,002,690$ & $-176,292$ & $-28,387$ & 17,539 & 29.0 & 949,025 \\
\hline & $\mathrm{SO}_{2}$ & 54,669 & $-1,436$ & -169 & 41 & 9.0 & 76,166 \\
\hline & $\mathrm{PM}_{2.5}$ & 25,973 & $-5,047$ & -493 & 439 & 3.0 & 30,127 \\
\hline & $\mathrm{NH}_{3}$ & 4,364 & -1.5 & 0.0 & 35 & 0.0 & 4,395 \\
\hline $\begin{array}{l}\mathrm{PM}_{2.5} \\
\text { changes }\end{array}$ & Min & -0.001 & -0.751 & -0.201 & -0.543 & -0.003 & $<0.000$ \\
\hline
\end{tabular}




\begin{tabular}{|c|c|c|c|c|c|c|c|}
\hline \multirow[t]{2}{*}{$(\mu \mathrm{g} / \mathrm{m} 3)$} & Mean & 0.065 & -0.011 & -0.001 & $<0.000$ & $<0.000$ & 0.080 \\
\hline & $\operatorname{Max}$ & 1.682 & 0.002 & 0.000 & 0.711 & 0.002 & 1.571 \\
\hline $\begin{array}{l}\text { Daily } \\
\mathrm{PM}_{2.5} \\
(>35 \mu \mathrm{g} / \\
\left.\mathrm{m}^{3}\right)\end{array}$ & Annual & 29 & -7 & 0 & 1 & 0 & 18 \\
\hline $\begin{array}{l}\text { Daily } \\
\mathrm{PM}_{2.5} \\
(>12 \mu \mathrm{g} / \\
\left.\mathrm{m}^{3}\right)\end{array}$ & Annual & 1 & -1 & -1 & 0 & 0 & 1 \\
\hline \multirow{3}{*}{$\begin{array}{l}\text { Ozone } \\
\text { changes } \\
\text { (ppbv) }\end{array}$} & Min & -0.423 & -1.256 & -1.214 & -0.465 & 0.000 & -0.119 \\
\hline & Mean & 0.602 & -0.134 & -0.025 & 0.005 & 0.003 & 0.726 \\
\hline & $\operatorname{Max}$ & 2.701 & 0.461 & 0.019 & 0.455 & 0.073 & 3.368 \\
\hline $\begin{array}{l}\text { Ozone } \\
\text { (>70ppb } \\
\text { v) }\end{array}$ & Annual & 634 & -29 & -8 & 2 & 0 & 139 \\
\hline \multirow{3}{*}{$\begin{array}{l}\mathrm{NO}_{2} \\
\text { changes } \\
\text { (ppbv) }\end{array}$} & Min & -0.014 & -6.782 & -6.708 & -4.057 & -0.001 & -0.01 \\
\hline & Mean & 0.170 & -0.036 & -0.006 & 0.000 & 0.000 & 0.166 \\
\hline & Max & 17.183 & 0.001 & 0.001 & 4.091 & 0.018 & 17.373 \\
\hline
\end{tabular}

Table 2: Health impacts of O\&G in 2016, in 2028 in a BAU scenario, and health benefits of different policy cases in 2028 compared to BAU. 


\begin{tabular}{|c|c|c|c|c|c|c|c|}
\hline & & \multicolumn{6}{|c|}{ Cases } \\
\hline \multirow[b]{2}{*}{$\begin{array}{l}\text { Health } \\
\text { Outcome }\end{array}$} & \multirow[b]{2}{*}{$\begin{array}{l}\text { Pollut } \\
\text { ant }\end{array}$} & \multirow[b]{2}{*}{2016} & \multirow[b]{2}{*}{$2028 \mathrm{BAU}$} & \multicolumn{4}{|c|}{2028 Benefits of Policies Compared to BAU } \\
\hline & & & & $\begin{array}{l}\text { Ambitious } \\
\text { Policy Case }\end{array}$ & Rollback & \begin{tabular}{|l|} 
Strong \\
State + \\
Federal \\
BAU
\end{tabular} & EPA Base \\
\hline $\begin{array}{l}\text { Deaths } \\
\text { (Vodonos et } \\
\text { al.) }\end{array}$ & $\mathrm{PM}_{2.5}$ & $\begin{array}{l}2,100 \\
(1,800- \\
2,400)\end{array}$ & \begin{tabular}{|l}
2,700 \\
$(2,200-$ \\
$3,100)$
\end{tabular} & \begin{tabular}{|l}
$310(260$ - \\
$360)$
\end{tabular} & $\begin{array}{l}14(12- \\
16)\end{array}$ & $44(37-51)$ & \begin{tabular}{|l}
$-7.1(-6$ - - \\
$8.3)$
\end{tabular} \\
\hline $\begin{array}{l}\text { Deaths } \\
\text { (Turner et al.) }\end{array}$ & O3 & $\begin{array}{l}2,600 \\
(1,300- \\
5,200)\end{array}$ & $\begin{array}{l}3,300 \\
(1,700- \\
6,600)\end{array}$ & $\begin{array}{l}600(300 \text { - } \\
1,200)\end{array}$ & $\begin{array}{l}-16(-8 \text { - - } \\
32)\end{array}$ & \begin{tabular}{|l}
$84(42-$ \\
$170)$
\end{tabular} & $\begin{array}{l}-24(-12-- \\
49)\end{array}$ \\
\hline \begin{tabular}{|l} 
Deaths \\
(Faustini et \\
al.)
\end{tabular} & $\mathrm{NO}_{2}$ & $\begin{array}{l}2,800 \\
(1,400- \\
4,100)\end{array}$ & \begin{tabular}{|l}
2,700 \\
$(1,400-$ \\
$4,100)$
\end{tabular} & $\begin{array}{l}520(260 \text { - } \\
780)\end{array}$ & $\begin{array}{l}0.0091(- \\
0.0046-- \\
0.014)\end{array}$ & $\begin{array}{l}91(46- \\
140)\end{array}$ & $\begin{array}{l}-18(-8.8- \\
-26)\end{array}$ \\
\hline $\begin{array}{l}\text { Cardiovascul } \\
\text { ar } \\
\text { Hospitalizatio } \\
\text { ns (Levy \& } \\
\text { Zanobetti } \\
\text { Pooled) }\end{array}$ & $\mathrm{PM}_{2.5}$ & $\begin{array}{l}110(74 \text { - } \\
140)\end{array}$ & $\begin{array}{l}140(95- \\
180)\end{array}$ & $16(11-21)$ & $\begin{array}{l}0.73(0.5- \\
0.96)\end{array}$ & $\begin{array}{l}2.2(1.5- \\
2.9)\end{array}$ & $\begin{array}{l}-0.36(- \\
0.25-- \\
0.47)\end{array}$ \\
\hline $\begin{array}{l}\text { Respiratory } \\
\text { Hospitalizatio } \\
\text { ns (Levy \& } \\
\text { Zanobetti } \\
\text { Pooled) }\end{array}$ & $\mathrm{PM}_{2.5}$ & $\begin{array}{l}110(58 \text { - } \\
170)\end{array}$ & $\begin{array}{l}140(74- \\
210)\end{array}$ & $17(8.7-25)$ & \begin{tabular}{|l}
$0.73(0.38$ \\
$-1.1)$
\end{tabular} & $\begin{array}{l}2.2(1.1- \\
3.2)\end{array}$ & $\begin{array}{l}-0.33(- \\
0.17-- \\
0.5)\end{array}$ \\
\hline
\end{tabular}




\begin{tabular}{|c|c|c|c|c|c|c|c|}
\hline $\begin{array}{l}\text { Heart Attacks } \\
\text { (Mustafić et } \\
\text { al.) }\end{array}$ & $\mathrm{PM}_{2.5}$ & $\begin{array}{l}96(57- \\
140)\end{array}$ & $\begin{array}{l}120(73- \\
180)\end{array}$ & $14(8.5-20)$ & $\begin{array}{l}0.64(0.38 \\
-0.92)\end{array}$ & $\begin{array}{l}1.9 \\
2.7)\end{array}$ & $\begin{array}{l}-0.33(-0.2 \\
--0.48)\end{array}$ \\
\hline $\begin{array}{l}\text { Heart Attacks } \\
\text { (Mustafić et } \\
\text { al.) }\end{array}$ & $\mathrm{NO}_{2}$ & $\begin{array}{l}170(94 \text { - } \\
250)\end{array}$ & $\begin{array}{l}170(93- \\
250)\end{array}$ & $31(17-46)$ & $\begin{array}{l}0.0043 \\
(0.0024- \\
0.0063)\end{array}$ & $\begin{array}{l}5.3(2.9- \\
7.8)\end{array}$ & $\begin{array}{l}-1(-0.55- \\
-1.5)\end{array}$ \\
\hline $\begin{array}{l}\text { Respiratory } \\
\text { Hospitalizatio } \\
\text { ns (Ji et al.) }\end{array}$ & O3 & $\begin{array}{l}1,300(490 \\
2,200)\end{array}$ & $\begin{array}{l}1,700(620 \\
-2,800)\end{array}$ & $\begin{array}{l}310(110- \\
510)\end{array}$ & $\begin{array}{l}-7.8(-2.8- \\
-13)\end{array}$ & $41(15-67)$ & $\begin{array}{l}-12(-4.2- \\
-19)\end{array}$ \\
\hline $\begin{array}{l}\text { Asthma } \\
\text { Incidence } \\
\text { (Khreis et al.) }\end{array}$ & $\mathrm{PM}_{2.5}$ & $\mid \begin{array}{l}800(270 \text { - } \\
1,300)\end{array}$ & $\begin{array}{l}990(330- \\
1,600)\end{array}$ & $\begin{array}{l}120(40 \text { - } \\
190)\end{array}$ & $\begin{array}{l}5(1.7- \\
8.3)\end{array}$ & $15(5-25)$ & $\begin{array}{l}-2.6(-0.88 \\
--4.3)\end{array}$ \\
\hline $\begin{array}{l}\text { Asthma } \\
\text { Incidence } \\
\text { (Khreis et al.) }\end{array}$ & $\mathrm{NO}_{2}$ & $\begin{array}{l}1,400(550 \\
1,900)\end{array}$ & $\begin{array}{l}1,300(530 \\
-1,800)\end{array}$ & $\begin{array}{l}270(110- \\
380)\end{array}$ & \begin{tabular}{|l|}
$-0.038(-$ \\
$0.016--$ \\
$0.053)$
\end{tabular} & $38(16-53)$ & $\begin{array}{l}-9.3(-3.8 \\
-13)\end{array}$ \\
\hline \begin{tabular}{|l} 
Asthma \\
Hospitalizatio \\
ns (Orellano \\
et al.)
\end{tabular} & $\mathrm{PM}_{2.5}$ & $6(0-12)$ & $7.6(0-15)$ & $\begin{array}{l}0.88(0 \text { - } \\
1.8)\end{array}$ & $\begin{array}{l}0.04(0- \\
0.081)\end{array}$ & $\begin{array}{l}0.13(0- \\
0.27)\end{array}$ & $\begin{array}{l}-0.029(0 \\
-0.059)\end{array}$ \\
\hline \begin{tabular}{|l|} 
Asthma \\
Hospitalizatio \\
ns (Orellano \\
et al.)
\end{tabular} & $\mathrm{NO}_{2}$ & \begin{tabular}{|l}
$47(1.2-$ \\
$93)$
\end{tabular} & $\begin{array}{l}45(1.2- \\
90)\end{array}$ & $9(0.23-18)$ & $\begin{array}{l}-0.0063(- \\
0.00016- \\
0.013)\end{array}$ & - & \begin{tabular}{|l}
$-0.33(-$ \\
$0.0083--$ \\
$0.65)$
\end{tabular} \\
\hline \begin{tabular}{|l|} 
Asthma ED \\
Visits \\
(Orellano et \\
al.)
\end{tabular} & $\mathrm{PM}_{2.5}$ & $63(0-130)$ & $79(0-160)$ & $9.7(0-20)$ & $\begin{array}{l}0.41(0- \\
0.83)\end{array}$ & $1.2(0-2.4)$ & $\begin{array}{l}-0.27(0- \\
0.55)\end{array}$ \\
\hline $\begin{array}{l}\text { Asthma ED } \\
\text { Visits } \\
\text { (Orellano et } \\
\text { al.) }\end{array}$ & $\mathrm{NO}_{2}$ & $\begin{array}{l}470(12- \\
930)\end{array}$ & $\begin{array}{l}460(12- \\
910)\end{array}$ & $\begin{array}{l}99(2.5- \\
200)\end{array}$ & $\begin{array}{l}-0.012(- \\
0.00029- \\
0.023)\end{array}$ & $\begin{array}{l}12(0.31- \\
24)\end{array}$ & $\begin{array}{l}-3(-0.077 \\
--6)\end{array}$ \\
\hline $\begin{array}{l}\text { Asthma } \\
\text { Exacerbation } \\
\text { s (Orellano et } \\
\text { al.) }\end{array}$ & $\mathrm{PM}_{2.5}$ & $\begin{array}{l}48,000(0- \\
98,000)\end{array}$ & $\begin{array}{l}60,000(0- \\
120,000)\end{array}$ & $\begin{array}{l}7,100(0- \\
14,000)\end{array}$ & $\begin{array}{l}310(0- \\
630)\end{array}$ & $\begin{array}{l}960(0- \\
1,900)\end{array}$ & $\begin{array}{l}-160(0- \\
330)\end{array}$ \\
\hline \begin{tabular}{|l|} 
Asthma \\
Exacerbation \\
s (Orellano et \\
al.)
\end{tabular} & $\mathrm{NO}_{2}$ & $\begin{array}{l}360,000 \\
(9,200- \\
710,000)\end{array}$ & $\begin{array}{l}350,000 \\
(8,900- \\
690,000)\end{array}$ & $\begin{array}{l}70,000 \\
(1,800- \\
140,000)\end{array}$ & $\begin{array}{l}-11(-0.27 \\
--21)\end{array}$ & $\begin{array}{l}11,000(280 \\
-22,000)\end{array}$ & $\begin{array}{l}-2,800(- \\
71-- \\
5,500)\end{array}$ \\
\hline
\end{tabular}




\begin{tabular}{|c|c|c|c|c|c|c|c|}
\hline $\begin{array}{l}\text { Low Birth } \\
\text { Weight (Sun } \\
\text { et al.) }\end{array}$ & $\mathrm{PM}_{2.5}$ & $5.6(2-9.2)$ & $7(2.5-11)$ & $\begin{array}{l}0.83(0.3- \\
1.3)\end{array}$ & $\mid \begin{array}{l}0.035 \\
(0.013- \\
0.057)\end{array}$ & $\begin{array}{l}0.11(0.038 \\
-0.17)\end{array}$ & $\begin{array}{l}-0.018(- \\
0.0064 \text { - } \\
0.029)\end{array}$ \\
\hline $\begin{array}{l}\text { Preterm Birth } \\
\text { (Sun et al.) }\end{array}$ & $\mathrm{PM}_{2.5}$ & $\begin{array}{l}15(3.5 \text { - } \\
26)\end{array}$ & $\mid \begin{array}{l}18(4.4 \text { - } \\
32)\end{array}$ & $\begin{array}{l}2.3(0.55 \text { - } \\
4)\end{array}$ & $\begin{array}{l}0.086 \\
(0.021- \\
0.15)\end{array}$ & $\begin{array}{l}0.25(0.06- \\
0.43)\end{array}$ & $\begin{array}{l}-0.046(- \\
0.011-- \\
0.08)\end{array}$ \\
\hline Deaths & $\begin{array}{l}\text { All } \\
\text { Three }\end{array}$ & $\begin{array}{l}7,500 \\
(4,500- \\
12,000)\end{array}$ & $\begin{array}{l}8,700 \\
(5,200- \\
14,000)\end{array}$ & $\begin{array}{l}1,400(820- \\
2,300)\end{array}$ & $\begin{array}{l}-2.2(3.7- \\
-16)\end{array}$ & $\begin{array}{l}220(120 \text { - } \\
360)\end{array}$ & $\begin{array}{l}-49(-27- \\
83)\end{array}$ \\
\hline $\begin{array}{l}\text { Asthma } \\
\text { Incidence }\end{array}$ & $\begin{array}{l}\mathrm{PM}_{2.5} \\
\text { and } \\
\mathrm{NO}_{2}\end{array}$ & $\begin{array}{l}2,200(830 \\
3,200)\end{array}$ & $\begin{array}{l}2,300(870 \\
-3,500)\end{array}$ & $\begin{array}{l}390(150 \text { - } \\
570)\end{array}$ & $\mid \begin{array}{l}5(1.7- \\
8.3)\end{array}$ & $53(21-78)$ & $\begin{array}{l}-12(-4.7- \\
-17)\end{array}$ \\
\hline $\begin{array}{l}\text { Asthma } \\
\text { Hospitalizatio } \\
\text { ns }\end{array}$ & $\begin{array}{l}\mathrm{PM}_{2.5} \\
\text { and } \\
\mathrm{NO}_{2}\end{array}$ & \begin{tabular}{|l}
$53(1.2-$ \\
$110)$
\end{tabular} & \begin{tabular}{|l}
$53(1.2-$ \\
$110)$
\end{tabular} & $\begin{array}{l}9.9(0.23 \text { - } \\
20)\end{array}$ & $\begin{array}{l}0.034(- \\
0.00016- \\
0.068)\end{array}$ & $\begin{array}{l}1.8(0.043- \\
3.6)\end{array}$ & \begin{tabular}{|l}
$-0.35(-$ \\
$0.0083--$ \\
$0.71)$
\end{tabular} \\
\hline $\begin{array}{l}\text { Asthma ED } \\
\text { Visits }\end{array}$ & $\begin{array}{l}\mathrm{PM}_{2.5} \\
\text { and } \\
\mathrm{NO}_{2}\end{array}$ & $\begin{array}{l}530(12- \\
1,100)\end{array}$ & $\begin{array}{l}540(12- \\
1,100)\end{array}$ & $\begin{array}{l}110(2.5 \text { - } \\
220)\end{array}$ & \begin{tabular}{|l}
$0.4(-$ \\
$0.00029-$ \\
$0.81)$
\end{tabular} & $\begin{array}{l}13(0.31 \text { - } \\
27)\end{array}$ & $\begin{array}{l}-3.3(- \\
0.077-- \\
6.6)\end{array}$ \\
\hline $\begin{array}{l}\text { Asthma } \\
\text { Exacerbation } \\
\text { s }\end{array}$ & $\begin{array}{l}\mathrm{PM}_{2.5} \\
\text { and } \\
\mathrm{NO}_{2}\end{array}$ & $\begin{array}{l}410,000 \\
(9,200- \\
810,000)\end{array}$ & $\begin{array}{l}410,000 \\
(8,900- \\
810,000)\end{array}$ & $\begin{array}{l}77,000 \\
(1,800- \\
150,000)\end{array}$ & $\begin{array}{l}300(-0.27 \\
-610)\end{array}$ & $\begin{array}{l}12,000(280 \\
-23,000)\end{array}$ & \begin{tabular}{|l}
$-2,900(-$ \\
$71--$ \\
$5,800)$
\end{tabular} \\
\hline $\begin{array}{l}\text { Respiratory } \\
\text { Hospitalizatio } \\
\text { ns }\end{array}$ & $\begin{array}{l}\mathrm{PM}_{2.5} \\
\text { and } \\
\text { Ozone }\end{array}$ & $\begin{array}{l}1,500(550 \\
2,400)\end{array}$ & $\begin{array}{l}1,800(690 \\
-3,000)\end{array}$ & $\begin{array}{l}320(120 \text { - } \\
530)\end{array}$ & $\begin{array}{l}-7.1(-2.4- \\
-12)\end{array}$ & $43(16-70)$ & $\begin{array}{l}-12(-4.4- \\
-20)\end{array}$ \\
\hline Heart Attacks & $\begin{array}{l}\mathrm{PM}_{2.5} \\
\text { and } \\
\mathrm{NO}_{2}\end{array}$ & $\begin{array}{l}270(150- \\
390)\end{array}$ & $\begin{array}{l}290(170 \text { - } \\
420)\end{array}$ & $45(26-66)$ & $\begin{array}{l}0.64(0.39 \\
-0.93)\end{array}$ & $7.2(4-10)$ & $\begin{array}{l}-1.3(-0.75 \\
--1.9)\end{array}$ \\
\hline & & \multicolumn{6}{|c|}{ Valuation (2016 USD) } \\
\hline & & & & \multicolumn{4}{|c|}{2028 Benefits of Policies Compared to BAU } \\
\hline $\begin{array}{l}\text { Health } \\
\text { Outcome }\end{array}$ & $\begin{array}{l}\text { Pollut } \\
\text { ant }\end{array}$ & 2016 & 2028 BAU & $\begin{array}{l}\text { Ambitious } \\
\text { Policy Case }\end{array}$ & Rollback & $\begin{array}{l}\text { Strong } \\
\text { State + } \\
\text { Federal } \\
\text { BAU }\end{array}$ & EPA Base \\
\hline $\begin{array}{l}\text { Deaths } \\
\text { (Vodonos et } \\
\text { al.) }\end{array}$ & $\mathrm{PM}_{2.5}$ & $\begin{array}{l}\$ 21 \text { billion } \\
(\$ 11 \text { billion } \\
-\$ 35 \\
\text { billion })\end{array}$ & $\begin{array}{l}\$ 28 \text { billion } \\
(\$ 14 \text { billion } \\
-\$ 45 \\
\text { billion })\end{array}$ & \begin{tabular}{|l|}
$\$ 3.2$ billion \\
$(\$ 1.6$ billion \\
$-\$ 5.2$ \\
billion $)$
\end{tabular} & $\begin{array}{l}\$ 140 \\
\text { million } \\
(\$ 74 \\
\text { million - }\end{array}$ & $\begin{array}{l}\$ 450 \text { million } \\
(\$ 230 \\
\text { million - } \\
\$ 740\end{array}$ & $\begin{array}{l}\$-73 \\
\text { million }(\$- \\
37 \text { million } \\
\$-120\end{array}$ \\
\hline
\end{tabular}




\begin{tabular}{|c|c|c|c|c|c|c|c|}
\hline & & & & & $\begin{array}{l}\$ 230 \\
\text { million) }\end{array}$ & (million) & (million) \\
\hline $\begin{array}{l}\text { Deaths } \\
\text { (Turner et al.) }\end{array}$ & $\mathrm{O} 3$ & $\begin{array}{l}\$ 27 \text { billion } \\
\text { (\$8 billion - } \\
\$ 76 \text { billion) }\end{array}$ & $\mid \begin{array}{l}\$ 34 \text { billion } \\
(\$ 10 \text { billion } \\
-\$ 96 \\
\text { billion })\end{array}$ & $\begin{array}{l}\$ 6.2 \text { billion } \\
(\$ 1.8 \text { billion } \\
-\$ 17 \text { billion })\end{array}$ & $\begin{array}{l}\$-160 \\
\text { million (\$- } \\
49 \text { million - } \\
\$-470 \\
\text { million) }\end{array}$ & \begin{tabular}{|l|}
$\$ 860$ million \\
$(\$ 260$ \\
million - \\
$\$ 2.5$ billion $)$
\end{tabular} & $\begin{array}{l}\$-250 \\
\text { million }(\$- \\
74 \text { million }- \\
\$-710 \\
\text { million) }\end{array}$ \\
\hline $\begin{array}{l}\text { Deaths } \\
\text { (Faustini et } \\
\text { al.) }\end{array}$ & $\mathrm{NO}_{2}$ & $\begin{array}{l}\$ 28 \text { billion } \\
(\$ 8.5 \text { billion } \\
-\$ 60 \\
\text { billion })\end{array}$ & $\mid \begin{array}{l}\$ 28 \text { billion } \\
(\$ 8.6 \text { billion } \\
-\$ 60 \\
\text { billion })\end{array}$ & $\begin{array}{l}\$ 5.4 \text { billion } \\
(\$ 1.6 \text { billion } \\
-\$ 11 \text { billion })\end{array}$ & $\mid \begin{array}{l}\$-94,000 \\
\$-28,000- \\
\$-200,000)\end{array}$ & \begin{tabular}{|l|}
$\$ 940$ million \\
$(\$ 280$ \\
million $-\$ 2$ \\
billion $)$
\end{tabular} & $\begin{array}{l}\$-190 \\
\text { million (\$- } \\
54 \text { million }- \\
\$-380 \\
\text { million) }\end{array}$ \\
\hline $\begin{array}{l}\text { Cardiovascul } \\
\text { ar } \\
\text { Hospitalizatio } \\
\text { ns (Levy \& } \\
\text { Zanobetti } \\
\text { Pooled) }\end{array}$ & $\mathrm{PM}_{2.5}$ & $\begin{array}{l}\$ 3.9 \text { million } \\
(\$ 2.7 \\
\text { million- } \$ 5.1 \\
\text { million) }\end{array}$ & $\begin{array}{l}\$ 5 \text { million } \\
(\$ 3.4 \\
\text { million - } \\
\$ 6.5 \\
\text { million) }\end{array}$ & $\begin{array}{l}\$ 570,000 \\
(\$ 390,000- \\
\$ 750,000)\end{array}$ & $\begin{array}{l}\$ 26,000 \\
(\$ 18,000 \\
\$ 34,000)\end{array}$ & $\begin{array}{l}\$ 79,000 \\
(\$ 54,000- \\
\$ 100,000)\end{array}$ & $\begin{array}{l}\$-13,000 \\
(\$-9,000- \\
\$-17,000)\end{array}$ \\
\hline $\begin{array}{l}\text { Hospitalizatio } \\
\text { ns (Levy \& } \\
\text { Zanobetti } \\
\text { Pooled) }\end{array}$ & $\mathrm{PM}_{2.5}$ & $\begin{array}{l}\$ 3.4 \text { million } \\
\text { ( } \$ 1.8 \text { million } \\
-\$ 5 \text { million })\end{array}$ & \begin{tabular}{|l}
$\$ 4.2$ million \\
$(\$ 2.2$ \\
million - \\
$\$ 6.3$ \\
million $)$
\end{tabular} & $\begin{array}{l}\$ 510,000 \\
(\$ 260,000- \\
\$ 750,000)\end{array}$ & $\begin{array}{l}\$ 22,000 \\
(\$ 11,000 \\
\$ 33,000)\end{array}$ & $\begin{array}{l}\$ 66,000 \\
(\$ 33,000- \\
\$ 96,000)\end{array}$ & $\begin{array}{l}\$-9,900 \\
(\$-5,100- \\
\$-15,000)\end{array}$ \\
\hline $\begin{array}{l}\text { Heart Attacks } \\
\text { (Mustafić et } \\
\text { al.) }\end{array}$ & $\mathrm{PM}_{2.5}$ & $\begin{array}{l}\$ 6.7 \text { million } \\
(\$ 4 \text { million - } \\
\$ 9.6 \text { million) }\end{array}$ & $\begin{array}{l}\$ 8.4 \text { million } \\
(\$ 5.1 \\
\text { million - } \\
\$ 13 \text { million })\end{array}$ & 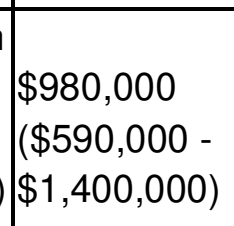 & $\begin{array}{l}\$ 45,000 \\
(\$ 27,000- \\
\$ 64,000)\end{array}$ & $\begin{array}{l}\$ 130,000 \\
(\$ 77,000- \\
\$ 190,000)\end{array}$ & \begin{tabular}{|l}
$\$-23,000$ \\
$(\$-14,000$ \\
$-\$-$ \\
$34,000)$
\end{tabular} \\
\hline $\begin{array}{l}\text { Heart Attacks } \\
\text { (Mustafić et } \\
\text { al.) }\end{array}$ & $\mathrm{NO}_{2}$ & $\begin{array}{l}\$ 12 \text { million } \\
(\$ 6.6 \\
\text { million- } \$ 18 \\
\text { million) }\end{array}$ & $\begin{array}{l}\$ 12 \text { million } \\
(\$ 6.5 \\
\text { million - } \\
\$ 17 \text { million })\end{array}$ & $\begin{array}{l}\$ 2.2 \text { million } \\
(\$ 1.2 \text { million } \\
-\$ 3.2 \\
\text { million })\end{array}$ & $\begin{array}{l}\$ 300 \\
(\$ 170- \\
\$ 440)\end{array}$ & $\begin{array}{l}\$ 370,000 \\
(\$ 200,000- \\
\$ 550,000)\end{array}$ & $\begin{array}{l}\$-70,000 \\
(\$-38,000 \\
-\$- \\
100,000)\end{array}$ \\
\hline $\begin{array}{l}\text { Respiratory } \\
\text { Hospitalizatio } \\
\text { ns (Ji et al.) }\end{array}$ & O3 & $\begin{array}{l}\$ 41 \text { million } \\
(\$ 15 \text { million } \\
-\$ 67 \\
\text { million })\end{array}$ & $\begin{array}{l}\$ 51 \text { million } \\
(\$ 19 \text { million } \\
-\$ 84 \\
\text { million })\end{array}$ & $\begin{array}{l}\$ 9.3 \text { million } \\
(\$ 3.3 \\
\text { million- } \$ 15 \\
\text { million })\end{array}$ & $\begin{array}{l}\$-230,000 \\
(\$-84,000- \\
\$-390,000)\end{array}$ & $\begin{array}{l}\$ 1.2 \text { million } \\
(\$ 450 \\
\text { thousand - } \\
\$ 2 \text { million })\end{array}$ & $\begin{array}{l}\$-360,000 \\
(\$-130,000 \\
-\$- \\
570,000)\end{array}$ \\
\hline $\begin{array}{l}\text { Asthma } \\
\text { Incidence } \\
\text { (Khreis et al.) }\end{array}$ & $\mathrm{PM}_{2.5}$ & $\begin{array}{l}\$ 47 \text { million } \\
(\$ 6.4 \text { million } \\
-\$ 120 \\
\text { million) }\end{array}$ & $\mid \begin{array}{l}\$ 58 \text { million } \\
(\$ 7.9 \\
\text { million - } \\
\$ 150 \\
\text { million })\end{array}$ & $\begin{array}{l}\$ 7 \text { million } \\
(\$ 950 \\
\text { thousand - } \\
\$ 18 \text { million })\end{array}$ & $\begin{array}{l}\$ 290,000 \\
(\$ 40,000- \\
\$ 770,000)\end{array}$ & \begin{tabular}{|l}
$\$ 880$ \\
thousand \\
$(\$ 120$ \\
thousand - \\
$\$ 2.3$ million)
\end{tabular} & $\begin{array}{l}\$-150,000 \\
(\$-21,000 \\
-\$- \\
400,000)\end{array}$ \\
\hline
\end{tabular}




\begin{tabular}{|c|c|c|c|c|c|c|c|}
\hline $\begin{array}{l}\text { Asthma } \\
\text { Incidence } \\
\text { (Khreis et al.) }\end{array}$ & $\mathrm{NO}_{2}$ & $\begin{array}{l}\$ 80 \text { million } \\
(\$ 13 \text { million } \\
-\$ 180 \\
\text { million })\end{array}$ & $\begin{array}{l}\$ 76 \text { million } \\
(\$ 13 \text { million } \\
-\$ 170 \\
\text { million })\end{array}$ & $\begin{array}{l}\$ 16 \text { million } \\
(\$ 2.6 \text { million } \\
-\$ 35 \\
\text { million })\end{array}$ & $\begin{array}{l}\$-2,200(\$- \\
380-\$- \\
4,900)\end{array}$ & $\begin{array}{l}\$ 2.2 \text { million } \\
(\$ 380 \\
\text { thousand- } \\
\$ 4.9 \text { million })\end{array}$ & $\begin{array}{l}\$-540 \\
\text { thousand } \\
(\$-90 \\
\text { thousand - } \\
\$-1.2 \\
\text { million) }\end{array}$ \\
\hline \begin{tabular}{|l} 
Asthma \\
Hospitalizatio \\
ns (Orellano \\
et al.)
\end{tabular} & $\mathrm{PM}_{2.5}$ & $\mid \begin{array}{l}\$ 110,000 \\
\$ 0- \\
\$ 220,000)\end{array}$ & $\mid \begin{array}{l}\$ 140,000 \\
(\$ 0- \\
\$ 270,000)\end{array}$ & $\begin{array}{l}\$ 16,000(\$ 0 \\
-\$ 33,000)\end{array}$ & $\begin{array}{l}\$ 730(\$ 0- \\
\$ 1,500)\end{array}$ & $\begin{array}{l}\$ 2,400(\$ 0- \\
\$ 4,900)\end{array}$ & $\begin{array}{l}\$-530(\$ 0 \\
-\$-1,100)\end{array}$ \\
\hline \begin{tabular}{|l} 
Asthma \\
Hospitalizatio \\
ns (Orellano \\
et al.)
\end{tabular} & $\mathrm{NO}_{2}$ & $\begin{array}{l}\$ 860,000 \\
(\$ 22,000- \\
\$ 1,700,000)\end{array}$ & $\begin{array}{l}\$ 820,000 \\
(\$ 22,000- \\
\$ 1,600,000\end{array}$ & $\begin{array}{l}\$ 160,000 \\
(\$ 4,200- \\
\$ 330,000)\end{array}$ & $\begin{array}{l}\$-120(\$- \\
2.9-\$- \\
240)\end{array}$ & $\mid \begin{array}{l}\$ 31,000 \\
(\$ 780- \\
\$ 62,000)\end{array}$ & $\mid \begin{array}{l}\$-6,000 \\
(\$-150-\$- \\
12,000)\end{array}$ \\
\hline $\begin{array}{l}\text { Asthma ED } \\
\text { Visits } \\
\text { (Orellano et } \\
\text { al.) }\end{array}$ & $\mathrm{PM}_{2.5}$ & $\begin{array}{l}\$ 28,000(\$ 0 \\
-\$ 60,000)\end{array}$ & $\mid \begin{array}{l}\$ 36,000 \\
(\$ 0- \\
\$ 75,000)\end{array}$ & $\begin{array}{l}\$ 4,400(\$ 0 \\
\$ 9,400)\end{array}$ & $\begin{array}{l}\$ 190(\$ 0 \\
\$ 390)\end{array}$ & $\begin{array}{l}\$ 540(\$ 0- \\
\$ 1,100)\end{array}$ & $\begin{array}{l}\$-120(\$ 0 \\
-\$-260)\end{array}$ \\
\hline $\begin{array}{l}\text { Asthma ED } \\
\text { Visits } \\
\text { (Orellano et } \\
\text { al.) }\end{array}$ & $\mathrm{NO}_{2}$ & $\begin{array}{l}\$ 210,000 \\
(\$ 5,200- \\
\$ 440,000)\end{array}$ & $\begin{array}{l}\$ 210,000 \\
(\$ 5,200- \\
\$ 430,000)\end{array}$ & $\begin{array}{l}\$ 45,000 \\
(\$ 1,100- \\
\$ 94,000)\end{array}$ & \begin{tabular}{|l}
$\$-5.4(\$-$ \\
$0.13-\$-$ \\
$11)$
\end{tabular} & $\begin{array}{l}\$ 5,400 \\
(\$ 130- \\
\$ 11,000)\end{array}$ & $\begin{array}{l}\$-1,400 \\
(\$-33-\$- \\
2,800)\end{array}$ \\
\hline $\begin{array}{l}\text { Asthma } \\
\text { Exacerbation } \\
\text { s (Orellano et } \\
\text { al.) }\end{array}$ & $\mathrm{PM}_{2.5}$ & \begin{tabular}{|l}
$\$ 2.9$ million \\
$(\$ 0-\$ 9.6$ \\
million $)$
\end{tabular} & $\begin{array}{l}\$ 3.6 \text { million } \\
(\$ 0-\$ 12 \\
\text { million) }\end{array}$ & \begin{tabular}{|l}
$\$ 420$ \\
thousand \\
$(\$ 0-\$ 1.4$ \\
million $)$
\end{tabular} & $\begin{array}{l}\$ 18,000 \\
(\$ 0- \\
\$ 62,000)\end{array}$ & \begin{tabular}{|}
$\$ 57,000(\$ 0$ \\
$-\$ 190,000)$
\end{tabular} & $\begin{array}{l}\$-9,500 \\
(\$ 0-\$- \\
33,000)\end{array}$ \\
\hline $\begin{array}{l}\text { Asthma } \\
\text { Exacerbation } \\
\text { s (Orellano et } \\
\text { al.) }\end{array}$ & $\mathrm{NO}_{2}$ & $\begin{array}{l}\$ 21 \text { million } \\
(\$ 200 \\
\text { thousand - } \\
\$ 70 \text { million })\end{array}$ & $\begin{array}{l}\$ 21 \text { million } \\
(\$ 190 \\
\text { thousand - } \\
\$ 68 \text { million) }\end{array}$ & $\begin{array}{l}\$ 4.2 \text { million } \\
(\$ 39 \\
\text { thousand - } \\
\$ 14 \text { million) }\end{array}$ & $\begin{array}{l}\$-660(\$- \\
5.8-\$- \\
2,100)\end{array}$ & $\begin{array}{l}\$ 660 \\
\text { thousand } \\
(\$ 6.1 \\
\text { thousand - } \\
\$ 2.2 \text { million) }\end{array}$ & $\begin{array}{l}\$-170,000 \\
(\$-1,500- \\
\$-540,000)\end{array}$ \\
\hline $\begin{array}{l}\text { Low Birth } \\
\text { Weight (Sun } \\
\text { et al.) }\end{array}$ & $\mathrm{PM}_{2.5}$ & $\begin{array}{l}\$ 89,000 \\
(\$ 32,000- \\
\$ 140,000)\end{array}$ & $\begin{array}{l}\$ 110,000 \\
(\$ 39,000- \\
\$ 170,000)\end{array}$ & $\begin{array}{l}\$ 13,000 \\
(\$ 4,700- \\
\$ 20,000)\end{array}$ & $\begin{array}{l}\$ 550 \\
(\$ 200- \\
\$ 900)\end{array}$ & $\begin{array}{l}\$ 1,700 \\
(\$ 600- \\
\$ 2,700)\end{array}$ & \begin{tabular}{|l}
$\$-280(\$-$ \\
$100-\$-$ \\
$460)$
\end{tabular} \\
\hline $\begin{array}{l}\text { Preterm Birth } \\
\text { (Sun et al.) }\end{array}$ & $\mathrm{PM}_{2.5}$ & $\begin{array}{l}\$ 4.8 \text { million } \\
(\$ 1.2 \\
\text { million- } \$ 8.4 \\
\text { million) }\end{array}$ & $\begin{array}{l}\$ 5.9 \text { million } \\
(\$ 1.4 \\
\text { million - } \\
\$ 11 \text { million })\end{array}$ & $\begin{array}{l}\$ 760 \\
\text { thousand } \\
(\$ 180 \\
\text { thousand- } \\
\$ 1.3 \text { million) }\end{array}$ & $\begin{array}{l}\$ 28,000 \\
(\$ 6,900- \\
\$ 49,000)\end{array}$ & $\begin{array}{l}\$ 82,000 \\
(\$ 20,000- \\
\$ 140,000)\end{array}$ & $\begin{array}{l}\$-15,000 \\
(\$-3,600- \\
\$-26,000)\end{array}$ \\
\hline
\end{tabular}




\begin{tabular}{|c|c|c|c|c|c|c|c|}
\hline eaths & \begin{tabular}{|l} 
All \\
Three
\end{tabular} & $\begin{array}{l}\$ 77 \text { billion } \\
(\$ 27 \text { billion } \\
-\$ 170 \\
\text { billion) }\end{array}$ & $\begin{array}{l}\$ 90 \text { billion } \\
(\$ 32 \text { billion } \\
-\$ 200 \\
\text { billion) }\end{array}$ & $\begin{array}{l}\$ 14 \text { billion } \\
\text { (\$5 billion - } \\
\$ 33 \text { billion) }\end{array}$ & \begin{tabular}{|l}
$\$-23$ \\
million \\
$(\$ 23$ \\
million - \$- \\
230 \\
million)
\end{tabular} & $\begin{array}{l}\$ 2.3 \text { billion } \\
(\$ 740 \\
\text { million - } \\
\$ 5.2 \text { billion })\end{array}$ & $\begin{array}{l}\$-500 \\
\text { million }(\$- \\
170 \text { million } \\
-\$-1.2 \\
\text { billion) }\end{array}$ \\
\hline $\begin{array}{l}\text { Asthma } \\
\text { Incidence }\end{array}$ & $\begin{array}{l}\mathrm{PM}_{2.5} \\
\text { and } \\
\mathrm{NO}_{2}\end{array}$ & $\begin{array}{l}\$ 130 \text { million } \\
(\$ 20 \text { million } \\
-\$ 300 \\
\text { million })\end{array}$ & $\begin{array}{l}\$ 130 \\
\text { million (\$21 } \\
\text { million - } \\
\$ 330 \\
\text { million) }\end{array}$ & $\begin{array}{l}\$ 23 \text { million } \\
\text { (\$3.6 million } \\
-\$ 53 \\
\text { million) }\end{array}$ & $\begin{array}{l}\$ 290,000 \\
(\$ 40,000- \\
\$ 770,000)\end{array}$ & $\begin{array}{l}\$ 3.1 \text { million } \\
(\$ 500 \\
\text { thousand - } \\
\$ 7.2 \text { million })\end{array}$ & \begin{tabular}{|l}
$\$-700$ \\
thousand \\
$(\$-110$ \\
thousand - \\
$\$-1.6$ \\
million $)$
\end{tabular} \\
\hline $\begin{array}{l}\text { Asthma } \\
\text { Hospitalizatio } \\
\text { ns }\end{array}$ & $\begin{array}{l}\mathrm{PM}_{2.5} \\
\text { and } \\
\mathrm{NO}_{2}\end{array}$ & $\begin{array}{l}\$ 970,000 \\
(\$ 22,000- \\
\$ 1,900,000)\end{array}$ & $\begin{array}{l}\$ 970,000 \\
(\$ 22,000- \\
\$ 2 \text { million })\end{array}$ & $\begin{array}{l}\$ 180,000 \\
(\$ 4,200- \\
\$ 370,000)\end{array}$ & $\begin{array}{l}\$ 620(\$- \\
2.9- \\
\$ 1,200)\end{array}$ & $\begin{array}{l}\$ 33,000 \\
(\$ 780- \\
\$ 66,000)\end{array}$ & $\begin{array}{l}\$-6,400 \\
(\$-150-\$- \\
13,000)\end{array}$ \\
\hline $\begin{array}{l}\text { Asthma ED } \\
\text { Visits }\end{array}$ & $\begin{array}{l}\mathrm{PM}_{2.5} \\
\text { and } \\
\mathrm{NO}_{2}\end{array}$ & $\begin{array}{l}\$ 240,000 \\
(\$ 5,200- \\
\$ 500,000)\end{array}$ & \begin{tabular}{|l}
$\$ 240,000$ \\
$(\$ 5,200-$ \\
$\$ 520,000)$
\end{tabular} & $\begin{array}{l}\$ 50,000 \\
(\$ 1,100- \\
\$ 100,000)\end{array}$ & $\begin{array}{l}\$ 180(\$- \\
0.13- \\
\$ 380)\end{array}$ & $\begin{array}{l}\$ 5,900 \\
(\$ 130- \\
\$ 13,000)\end{array}$ & \begin{tabular}{|l}
$\$-1,500$ \\
$(\$-33-\$-$ \\
$3,100)$
\end{tabular} \\
\hline $\begin{array}{l}\text { Asthma } \\
\text { Exacerbation } \\
\text { s }\end{array}$ & $\begin{array}{l}\mathrm{PM}_{2.5} \\
\text { and } \\
\mathrm{NO}_{2}\end{array}$ & $\begin{array}{l}\$ 24 \text { million } \\
(\$ 200,000- \\
\$ 80 \text { million })\end{array}$ & $\begin{array}{l}\$ 24 \text { million } \\
(\$ 190,000- \\
\$ 80 \text { million })\end{array}$ & $\begin{array}{l}\$ 4.6 \text { million } \\
(\$ 39 \\
\text { thousand - } \\
\$ 15 \text { million) }\end{array}$ & $\mid \begin{array}{l}\$ 18,000 \\
(\$-5.8- \\
\$ 60,000)\end{array}$ & $\begin{array}{l}\$ 720 \\
\text { thousand } \\
(\$ 6 \\
\text { thousand - } \\
\$ 2.3 \text { million) }\end{array}$ & $\begin{array}{l}\$-170,000 \\
(\$-1,500- \\
\$-570,000)\end{array}$ \\
\hline $\begin{array}{l}\text { Respiratory } \\
\text { Hospitalizatio } \\
\text { ns }\end{array}$ & $\begin{array}{l}\mathrm{PM}_{2.5} \\
\text { and } \\
\text { Ozone }\end{array}$ & $\begin{array}{l}\$ 44 \text { million } \\
(\$ 16 \text { million } \\
-\$ 72 \\
\text { million) }\end{array}$ & $\begin{array}{l}\text { \$54 million } \\
(\$ 21 \text { million } \\
-\$ 90 \\
\text { million) }\end{array}$ & $\begin{array}{l}\$ 9.6 \text { million } \\
(\$ 3.6 \text { million } \\
-\$ 16 \\
\text { million) }\end{array}$ & $\begin{array}{l}\$-210,000 \\
(\$-72,000- \\
\$-360,000)\end{array}$ & $\begin{array}{l}\$ 1.3 \text { million } \\
(\$ 480 \\
\text { thousand - } \\
\$ 2.1 \text { million) }\end{array}$ & $\begin{array}{l}\$-360,000 \\
(\$-130,000 \\
-\$- \\
600,000)\end{array}$ \\
\hline Heart Attacks & $\begin{array}{l}\mathrm{PM}_{2.5} \\
\text { and } \\
\mathrm{NO}_{2}\end{array}$ & $\begin{array}{l}\$ 19 \text { million } \\
(\$ 11 \text { million } \\
-\$ 27 \\
\text { million })\end{array}$ & $\begin{array}{l}\$ 20 \text { million } \\
(\$ 12 \text { million } \\
-\$ 29 \\
\text { million })\end{array}$ & $\begin{array}{l}\$ 3.1 \text { million } \\
(\$ 1.8 \text { million } \\
-\$ 4.6 \\
\text { million) }\end{array}$ & $\begin{array}{l}\$ 45,000 \\
(\$ 27,000- \\
\$ 65,000)\end{array}$ & $\begin{array}{l}\$ 500,000 \\
(\$ 280,000- \\
\$ 700,000)\end{array}$ & $\begin{array}{l}\$-91,000 \\
(\$-52,000 \\
-\$- \\
130,000)\end{array}$ \\
\hline Grand Total & & $\begin{array}{l}\$ 77 \text { billion } \\
(\$ 27 \text { billion } \\
-\$ 170 \\
\text { billion })\end{array}$ & $\begin{array}{l}\$ 90 \text { billion } \\
(\$ 32 \text { billion } \\
-\$ 200 \\
\text { billion) }\end{array}$ & $\begin{array}{l}\$ 14 \text { billion } \\
\text { ( } \$ 5.1 \text { billion } \\
-\$ 34 \text { billion })\end{array}$ & \begin{tabular}{|l}
$\$-22$ \\
million \\
$(\$ 23$ \\
million - \$- \\
230 \\
million)
\end{tabular} & $\begin{array}{l}\$ 2.3 \text { billion } \\
(\$ 740 \\
\text { million - } \\
\$ 5.2 \text { billion })\end{array}$ & $\begin{array}{l}\$-510 \\
\text { million }(\$- \\
170 \text { million } \\
-\$-1.2 \\
\text { billion) }\end{array}$ \\
\hline
\end{tabular}




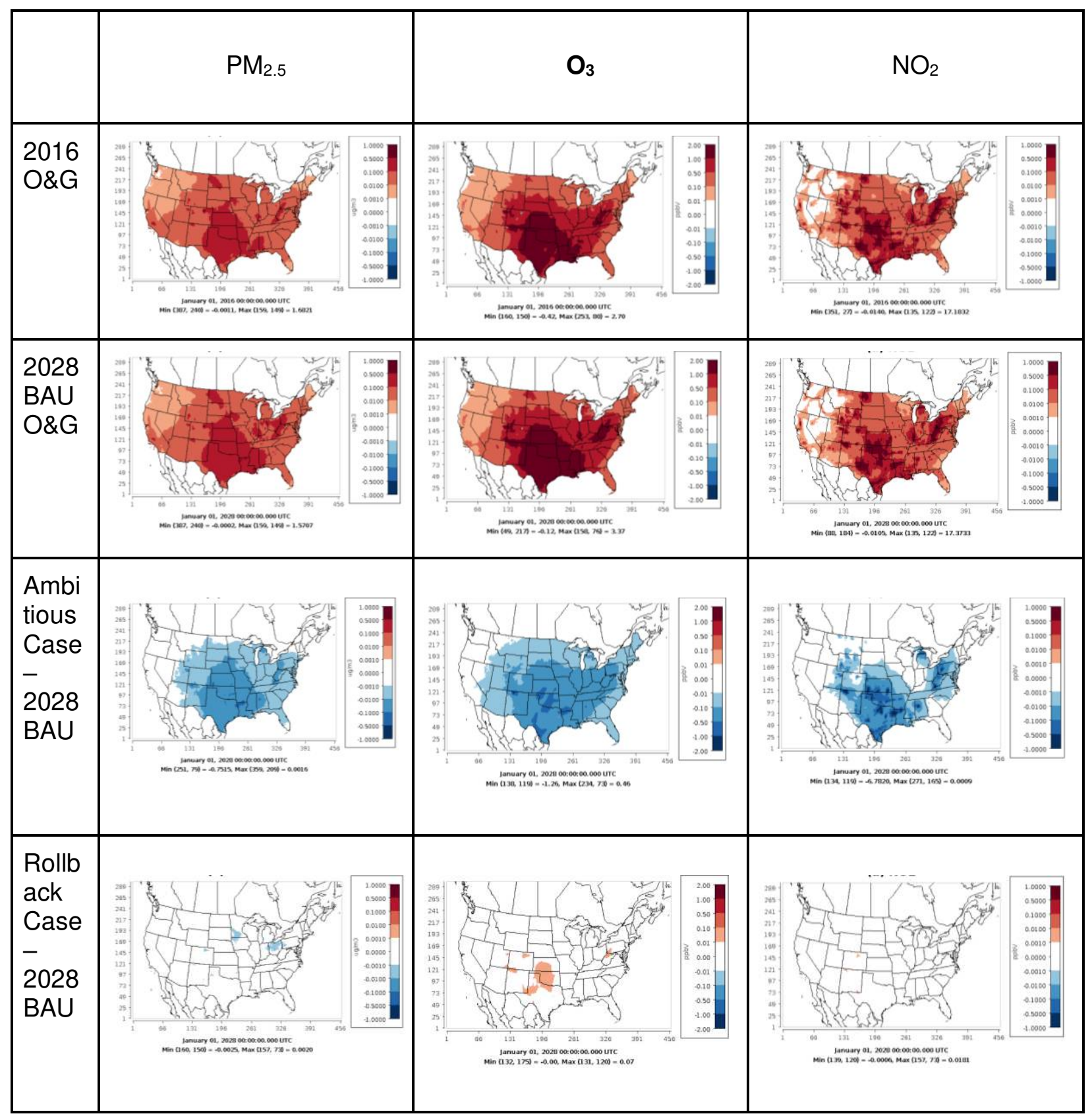

Fig. 1: Change in annual average concentration of pollutants due to $O \& G$ air pollution in 2016, health impacts of O\&G air pollution in 2028 under a "business as usual" scenario, and health benefits of an ambitious policy case and a policy rollback case in 2028 , compared to BAU. 


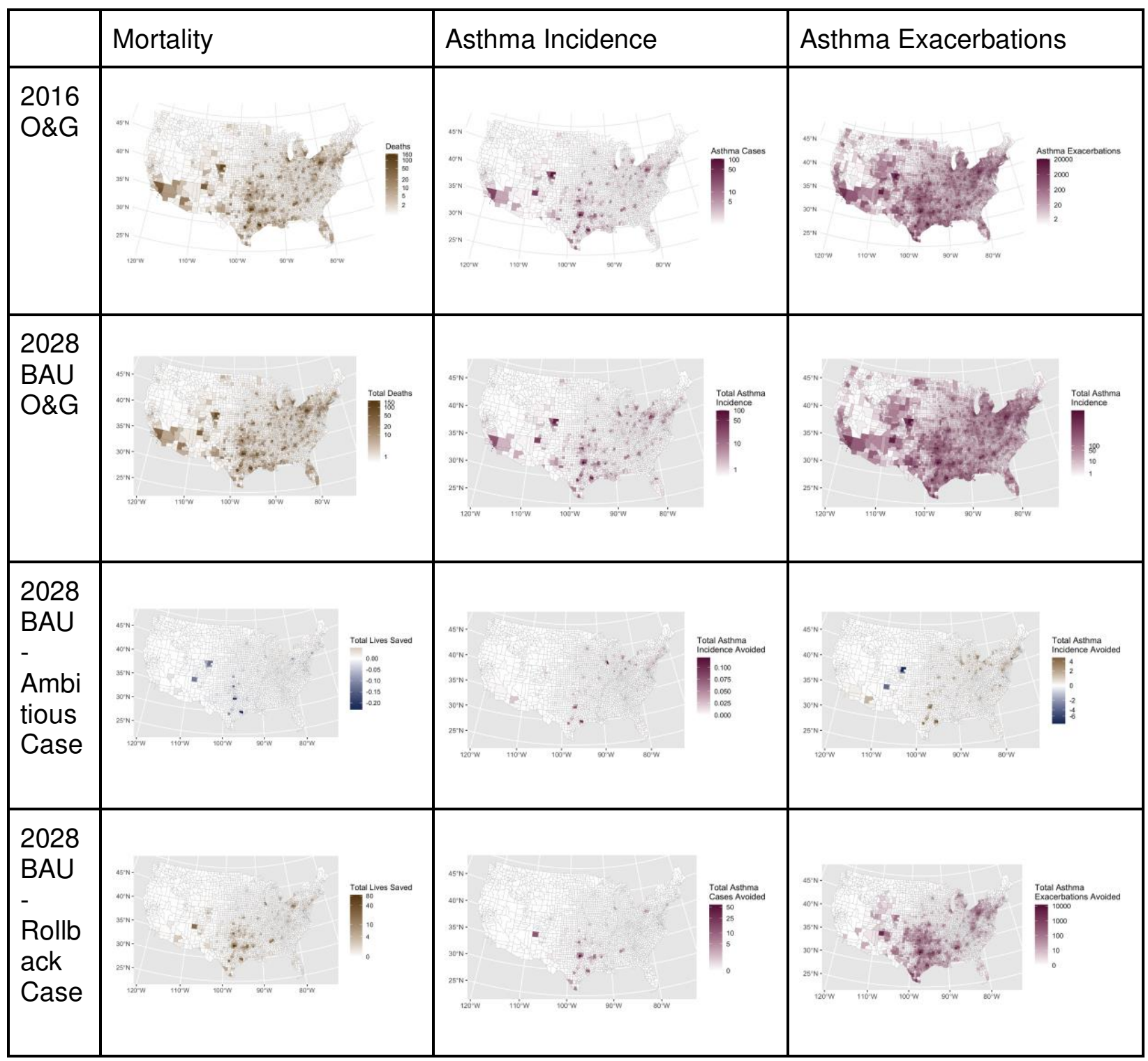

Fig. 2: Health impacts of O\&G air pollution in 2016, health impacts of O\&G air pollution in 2028 under a "business as usual" scenario, and health benefits of an ambitious policy case and a policy rollback case in 2028 , compared to BAU. 

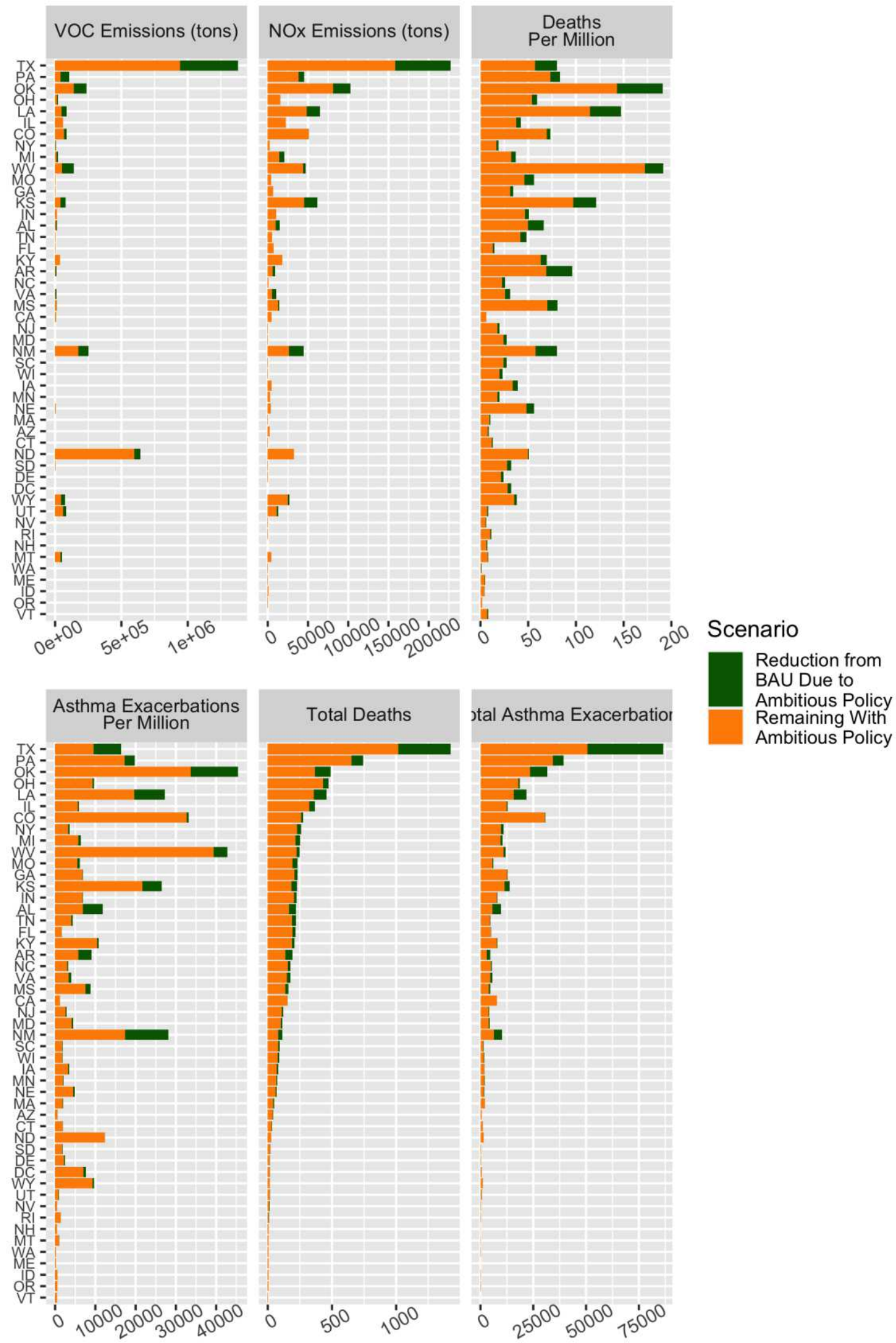
Fig 3: State level impacts of oil \& gas production in 2028, and state level benefits of an ambitious methane reduction policy in terms of emissions reductions and deaths and asthma exacerbations avoided, both total and per million people.

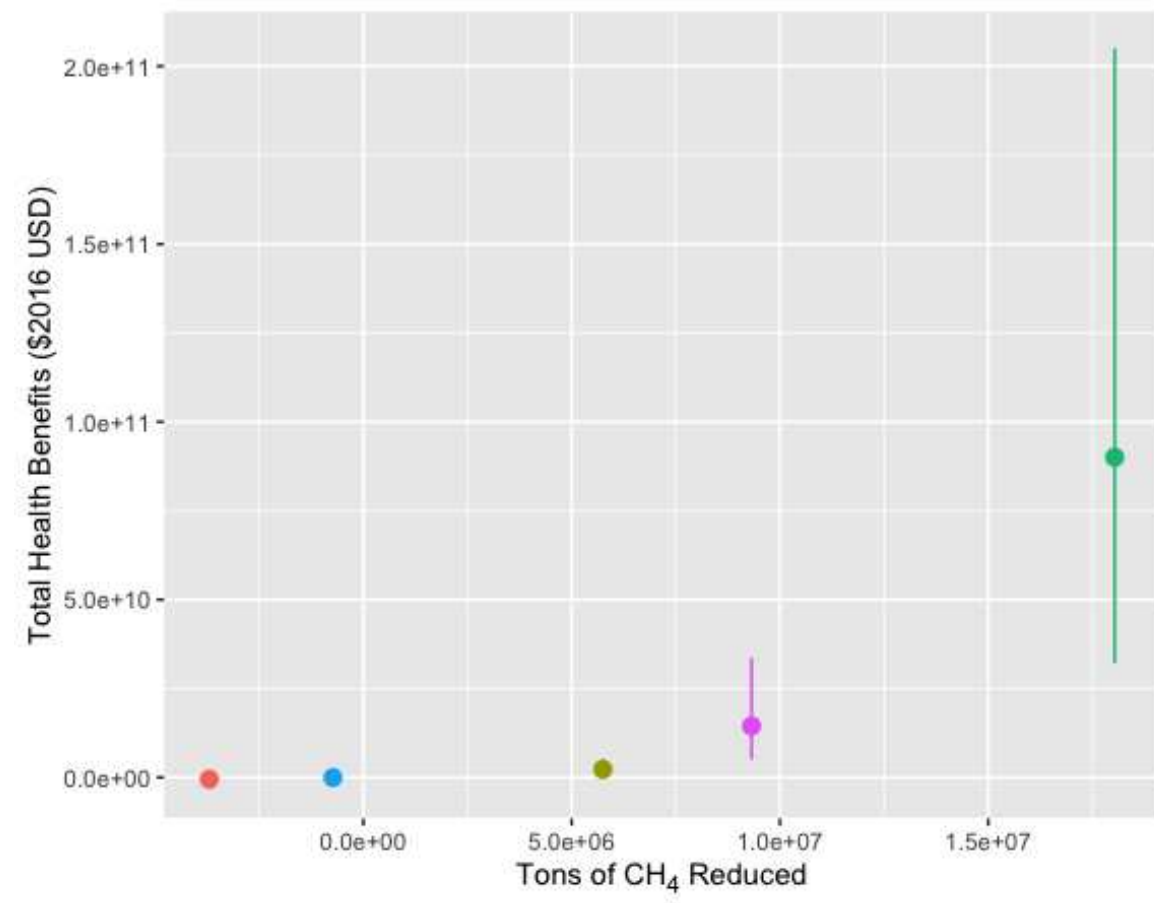

2028 Scenario

EPA Base Case

Federal BAU and Strong State

$\$$ Full Burden of O\&G

Rollback

Strong Federal and Strong State

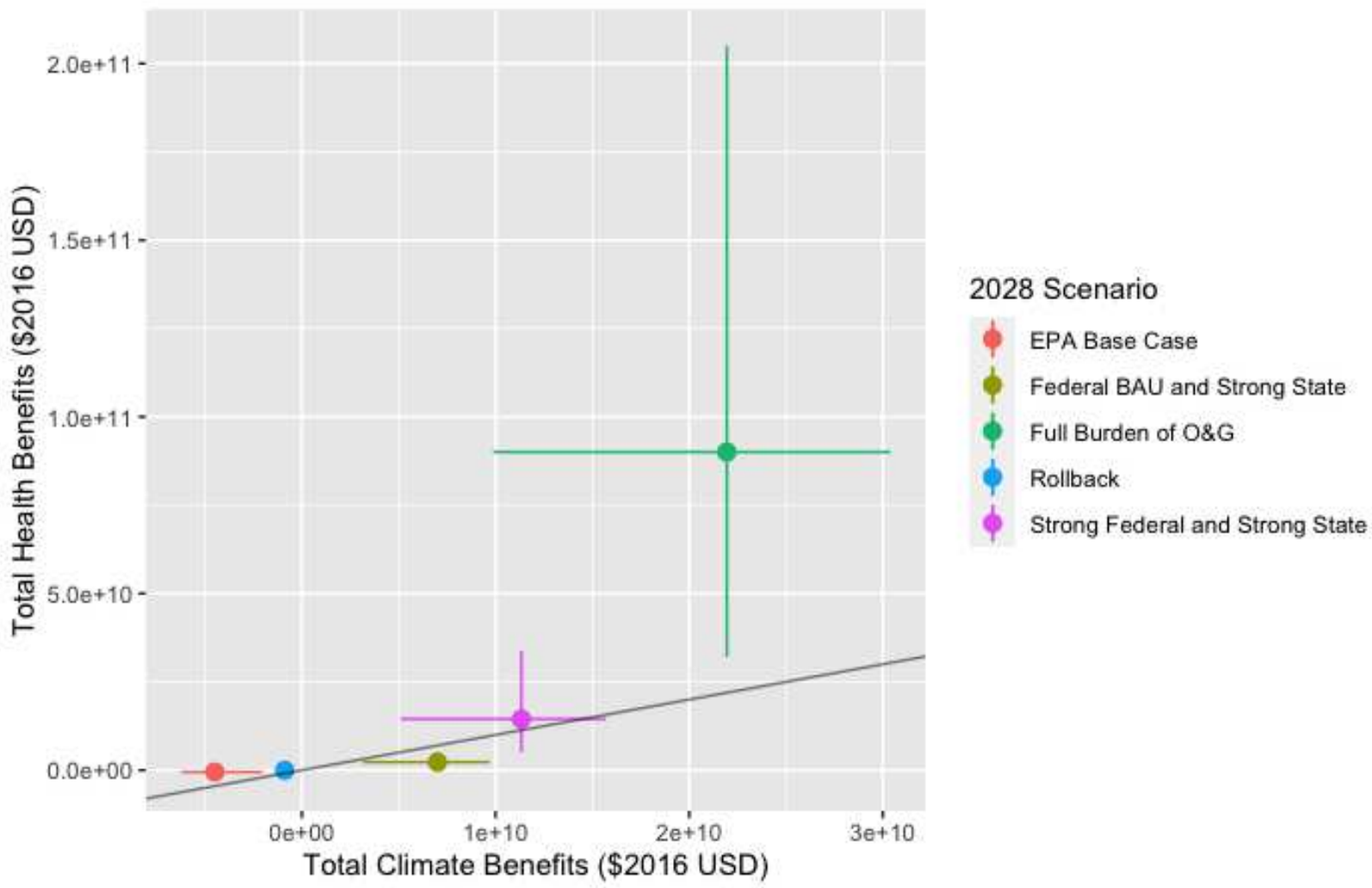


Fig 4: $\$$ value of health co-benefits per ton $\mathrm{CH}_{4}$ reduced under each policy, and comparison of health costs and social cost of methane. Areas above the grey line are where health benefits exceed climate benefits. 
Figures

\begin{tabular}{|c|c|c|c|c|c|c|}
\hline & $\mathrm{PM}_{2.5}$ & & $\mathrm{O}_{3}$ & & $\mathrm{NO}_{2}$ & \\
\hline $\begin{array}{l}2016 \\
\text { O\&G }\end{array}$ & 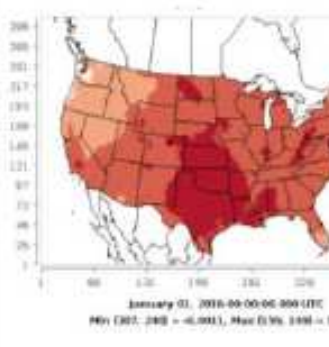 & 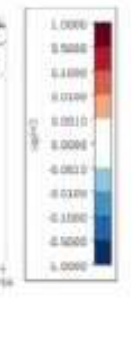 & 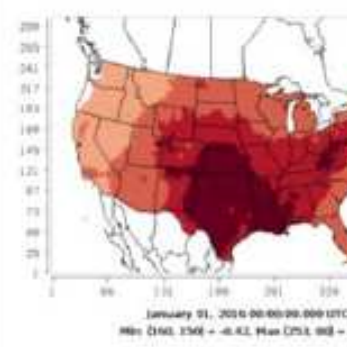 & 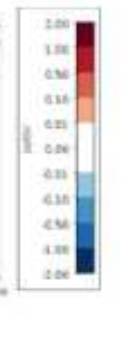 & 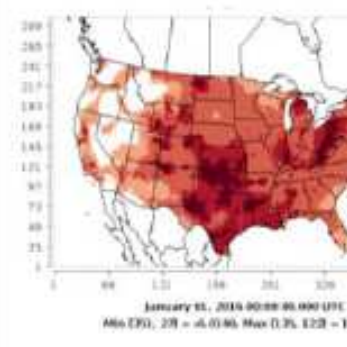 & 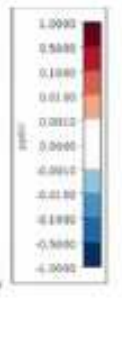 \\
\hline $\begin{array}{l}2028 \\
B A U \\
O \& G\end{array}$ & 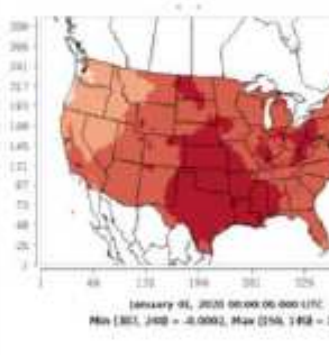 & 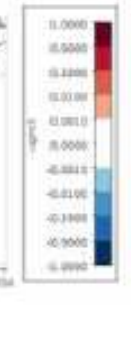 & 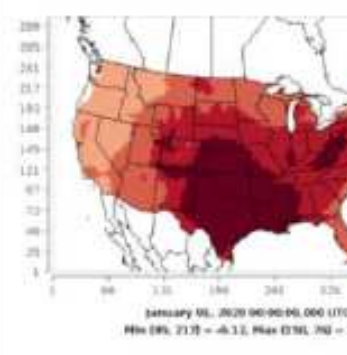 & 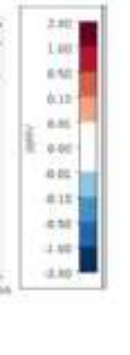 & 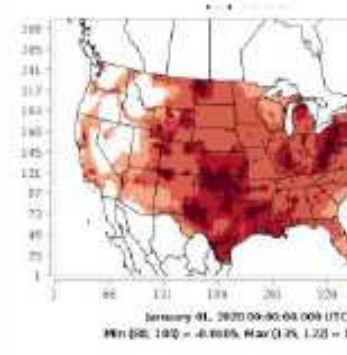 & 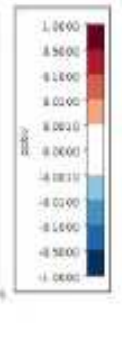 \\
\hline $\begin{array}{l}\text { Ambi } \\
\text { tious } \\
\text { Case } \\
- \\
2028 \\
\text { BAU }\end{array}$ & 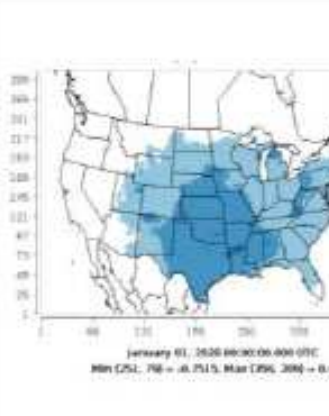 & 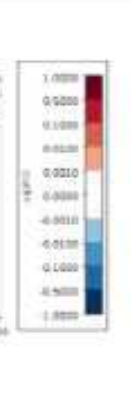 & : & 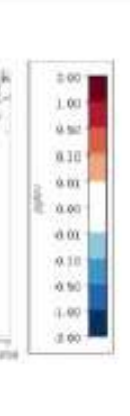 & $=\frac{2+1}{2+1}$ & 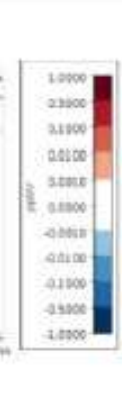 \\
\hline $\begin{array}{l}\text { Rollb } \\
\text { ack } \\
\text { Case } \\
- \\
2028 \\
\text { BAU }\end{array}$ & 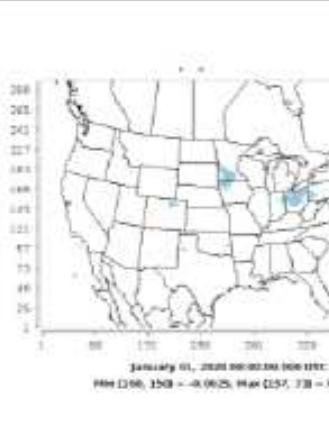 & $=0$ & 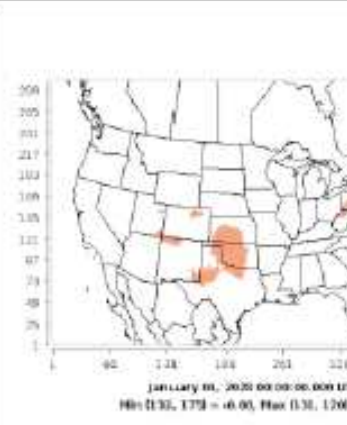 & 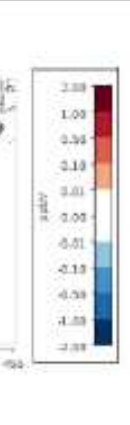 & inter & 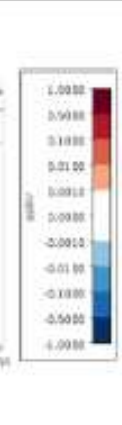 \\
\hline
\end{tabular}

Figure 1

Change in annual average concentration of pollutants due to $0 \& G$ air pollution in 2016 , health impacts of O\&G air pollution in 2028 under a "business as usual" scenario, and health benefits of an ambitious policy case and a policy rollback case in 2028 , compared to BAU. 


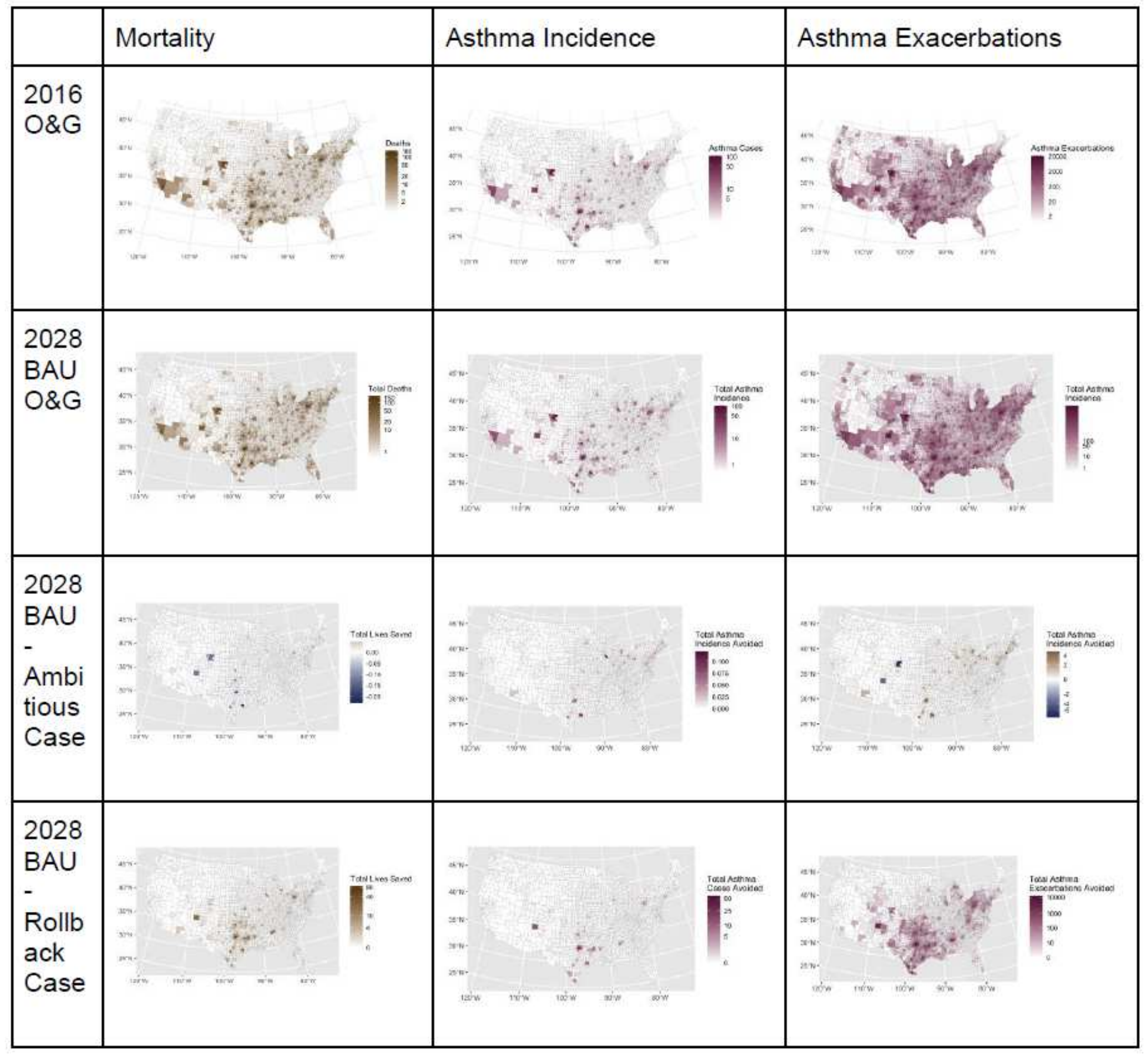

Figure 2

Health impacts of O\&G air pollution in 2016, health impacts of O\&G air pollution in 2028 under a "business as usual" scenario, and health benefits of an ambitious policy case and a policy rollback case in 2028 , compared to BAU. 

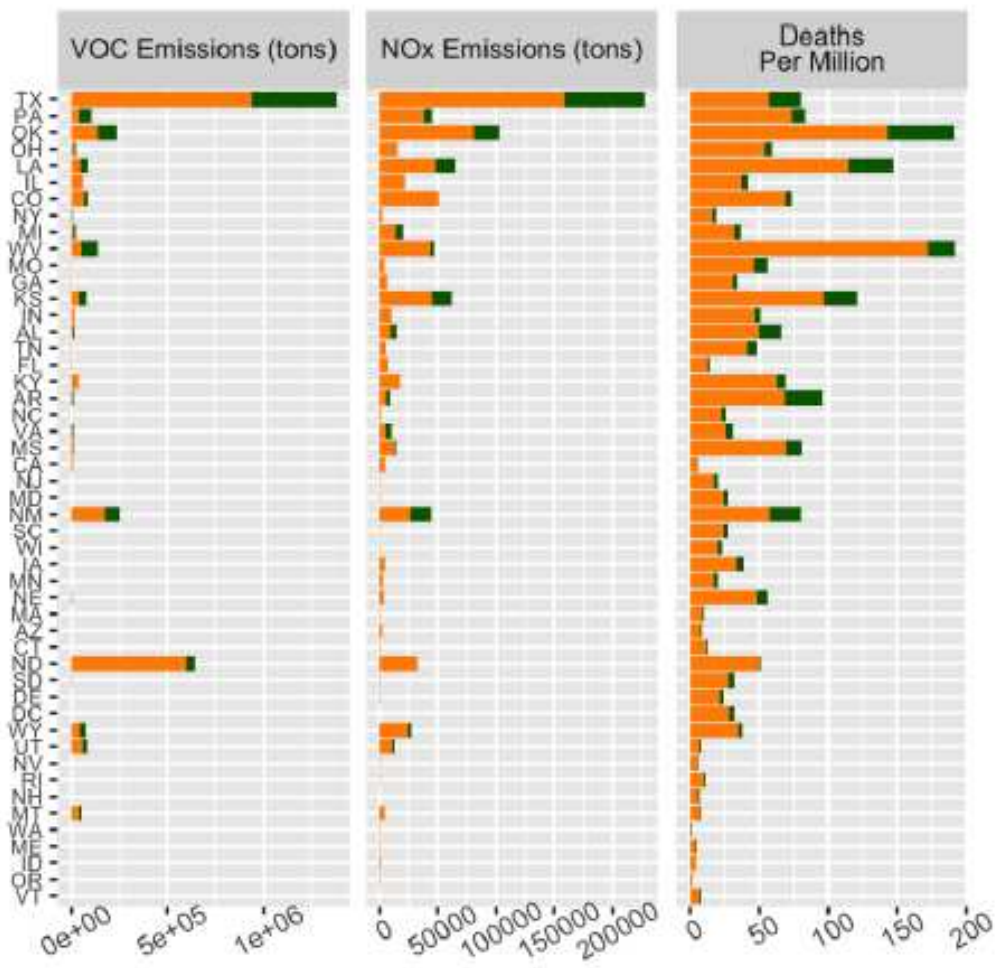

\section{Scenario}
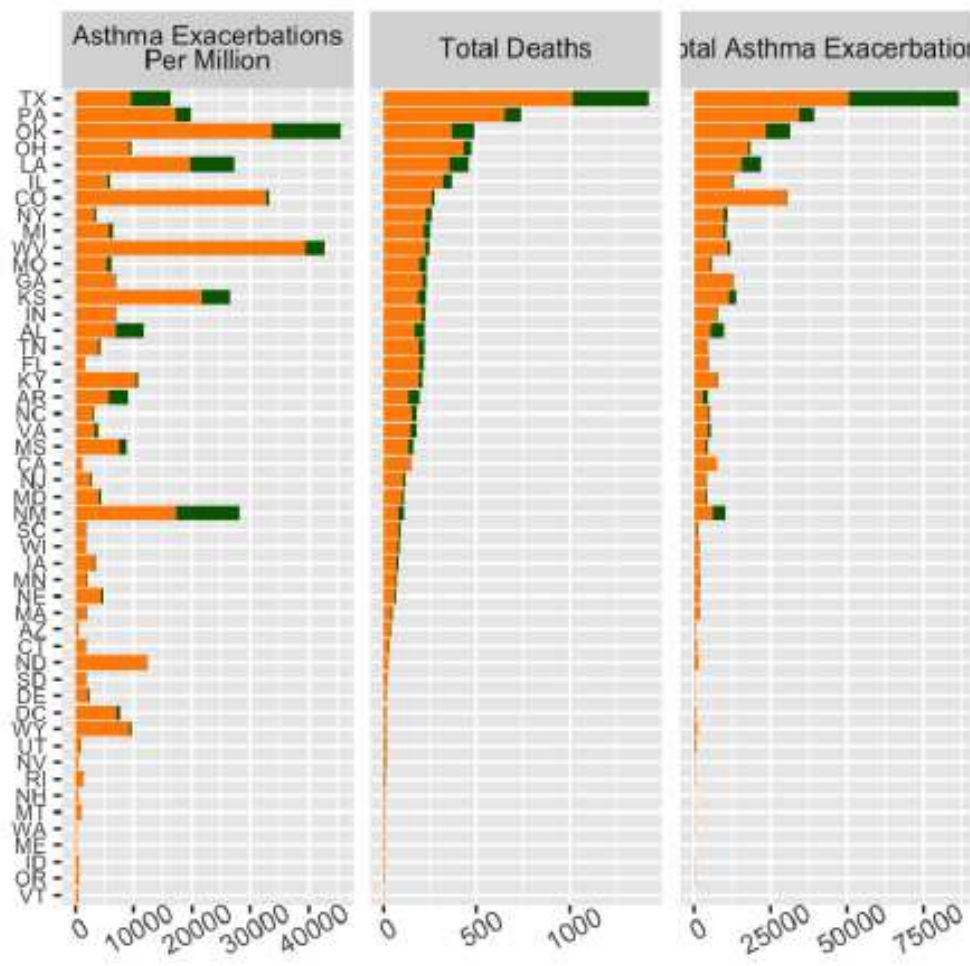

Reduction from BAU Due to Ambitious Policy Remaining With Ambitious Policy

\section{Figure 3}

State level impacts of oil \& gas production in 2028, and state level benefits of an ambitious methane reduction policy in terms of emissions reductions and deaths and asthma exacerbations avoided, both total and per million people. 

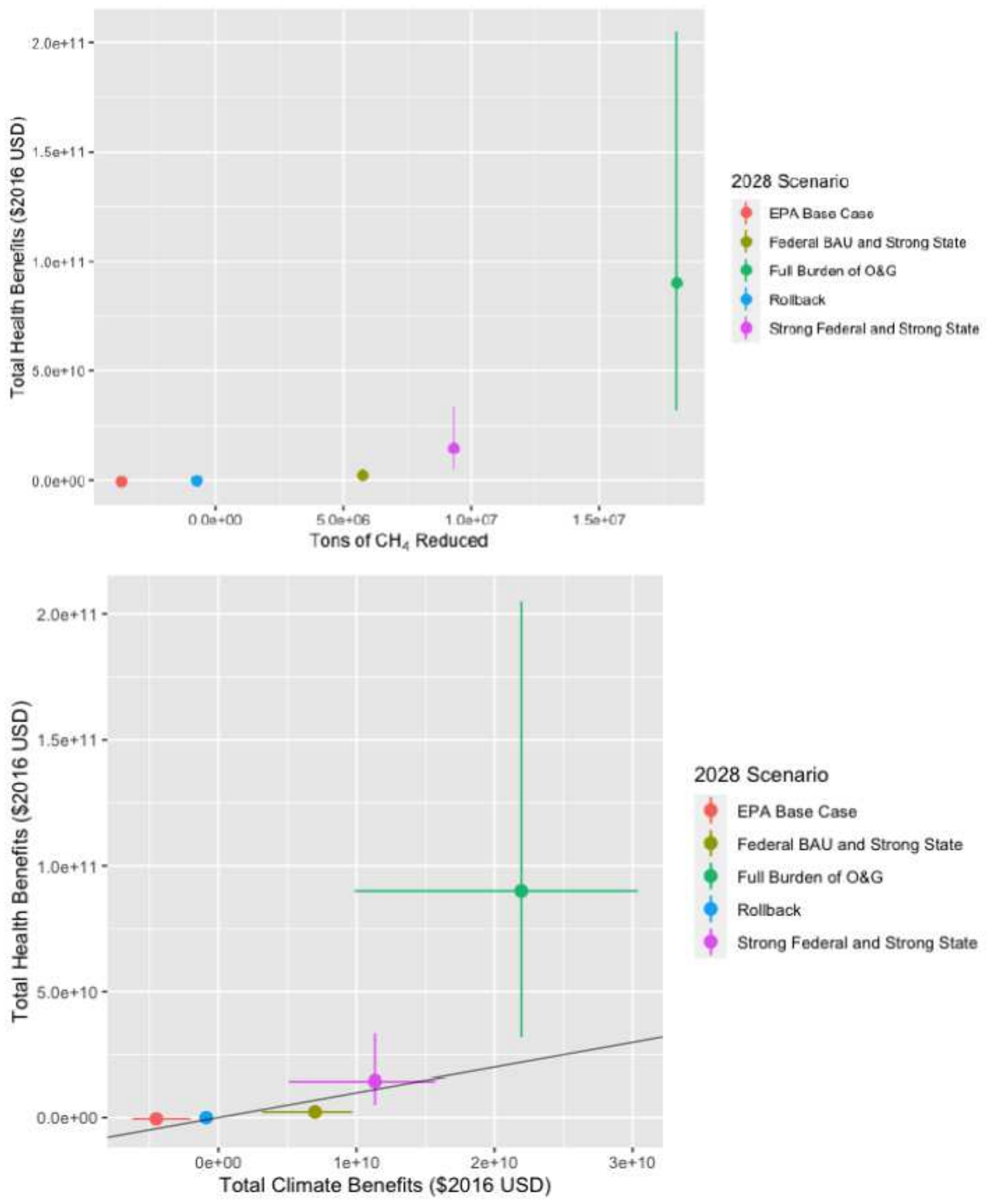

Figure 4

\$ value of health co-benefits per ton $\mathrm{CH} 4$ reduced under each policy, and comparison of health costs and social cost of methane. Areas above the grey line are where health benefits exceed climate benefits.

\section{Supplementary Files}


This is a list of supplementary files associated with this preprint. Click to download.

- SIXXXClimateandHealthBenefitsofMethanePoliciesintheUnitedStatesOilXGasSector.pdf 